\title{
AFFORDABLE HOMEOWNERSHIP: SOLUTIONS FOR ALLEVIATING MISSISSAUGA'S AFFORDABLE HOUSING ISSUE
}

\author{
By \\ Jennifer Lynn Ormiston \\ BA, Wilfrid Laurier University, 2014 \\ A Major Research Paper \\ Presented to Ryerson University \\ In partial fulfillment of the requirements for the degree of \\ Master of Planning \\ In \\ Urban Development
}

Toronto, Ontario, Canada, 2017

(c) Jennifer Ormiston 2017 


\section{Author's Declaration for Electronic Submission of a MRP}

I hereby declare that I am the sole author of this MRP. This is a true copy of the MRP, including any required final revisions.

I authorize Ryerson University to lend this MRP to other institutions or individuals for the purpose of scholarly research

I further authorize Ryerson University to reproduce this MRP by photocopying or by other means, in total or in part, at the request of other institutions or individuals for the purpose of scholarly research.

I understand that my MRP may be made electronically available to the public. 


\title{
AFFORDABLE HOMEOWNERSHIP: SOLUTIONS FOR ALLEVIATING MISSISSAUGA'S AFFORDABLE HOUSING ISSUE
}

(C) Jennifer Ormiston, 2017

\author{
Master of Planning \\ In \\ Urban Development \\ Ryerson University
}

\begin{abstract}
This research looks at literature, market trends, and policies and programs pertaining to affordable homeownership. The literature suggests that homeownership contributes to local economies and quality of life and is an important part of creating vibrant societies. This research is important as planning plays a vital role in representing those who cannot represent themselves and ensuring that a high quality of life is accessible to everyone. It explores the affordable housing issue in Mississauga and identifies the programs that currently exist to alleviate affordable housing issues. The recommendations are intended to guide Mississauga in the next steps of alleviating affordable homeownership issues. The recommendations provided are transient and can be used as a template for other municipalities in the Greater Golden Horseshoe Area alleviate similar issues.
\end{abstract}

Key words:

1. A paper on alleviating affordable homeownership issues in Mississauga, used the key words: affordable, homeownership, Mississauga, affordability issue. 


\section{TABLE OF CONTENTS}

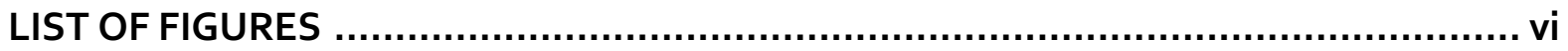

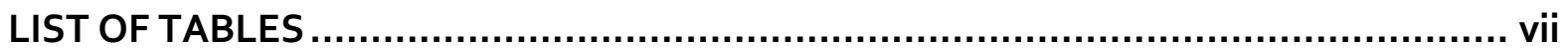

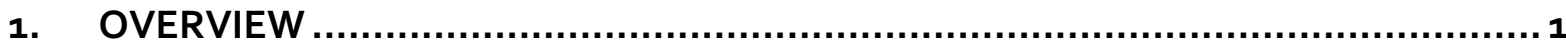

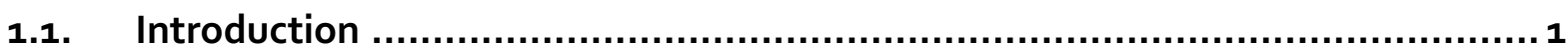

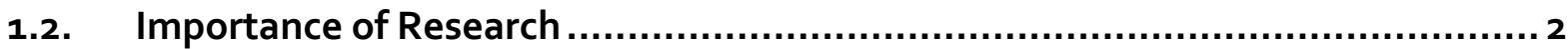

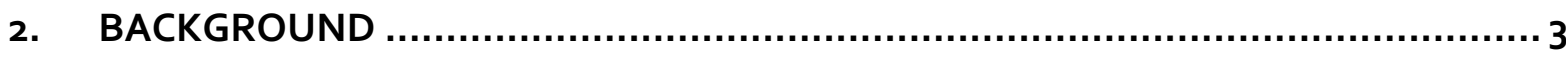

2.1. Literature Review...................................................................... 3

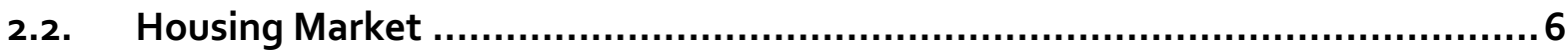

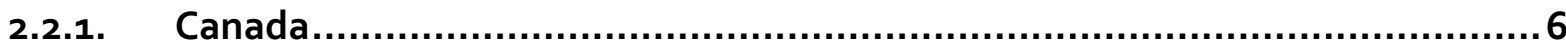

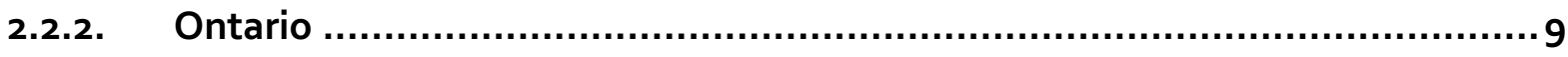

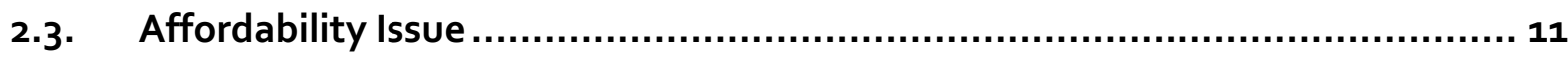

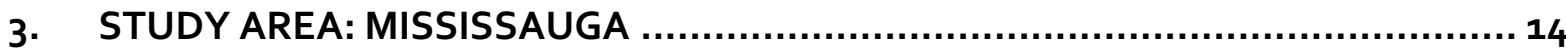

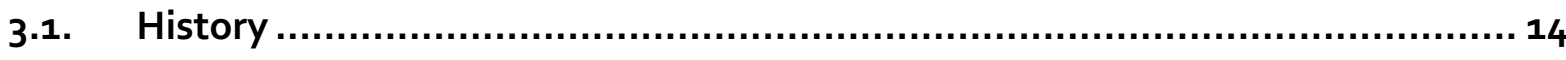

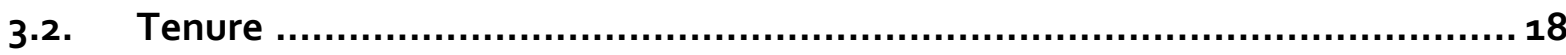

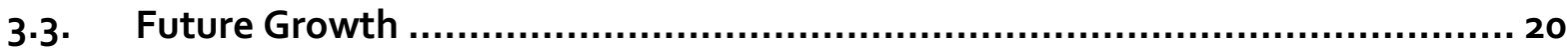

3.4. Housing Affordability in Mississauga .............................................. 22

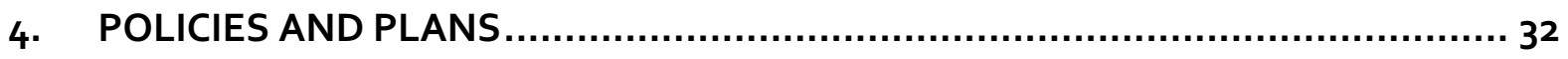

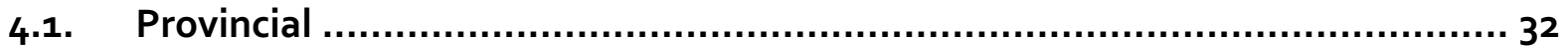

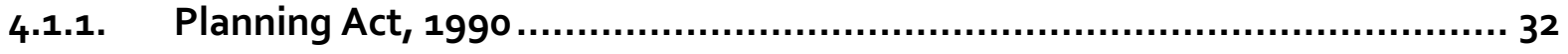

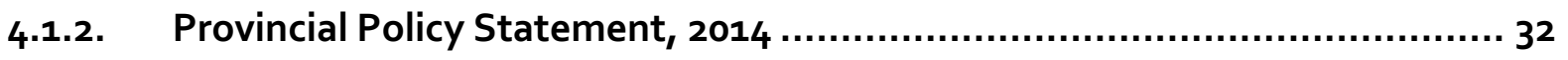

4.1.3. Proposed Growth Plan for the Greater Golden Horseshoe, 2016 ............... 33

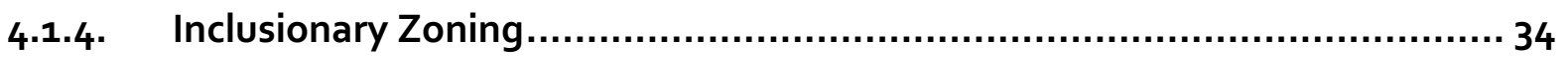

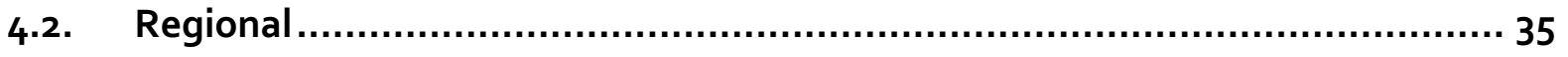

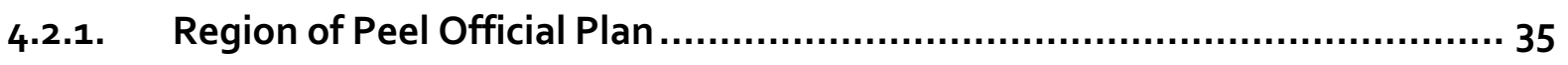

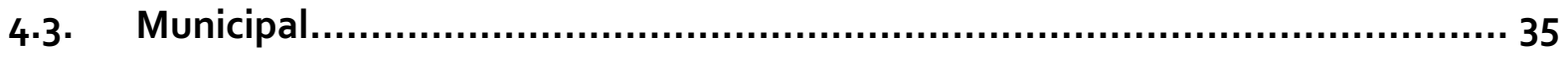

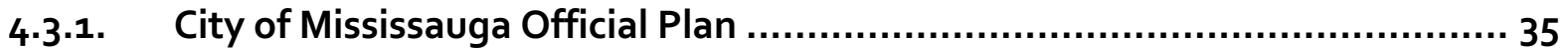

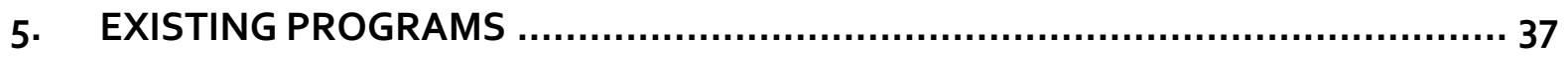

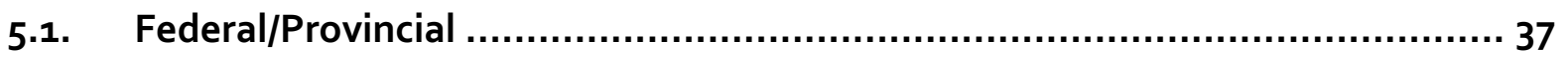

5.1.1. Canada Mortgage and Housing Corporation - Affordable Housing Programs in Ontario ..................................................................................... 37

5.1.2. Ontario's Long-Term Affordable Housing Strategy Update ..................... 38 


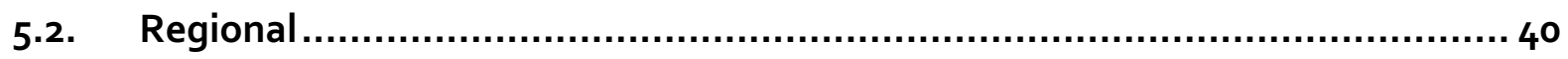

5.2.1. Peel's Housing and Homelessness Plan 2014-2024 …............................. 40

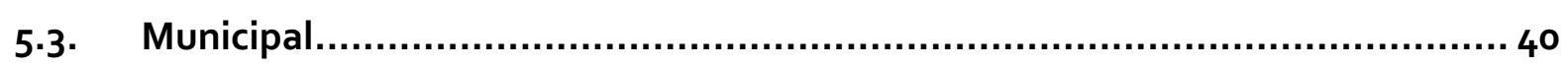

5.3.1. Mississauga's Affordable Housing Program ......................................... 40

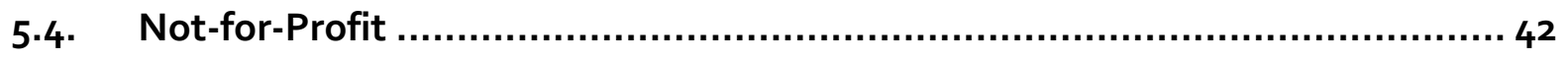

5.4.1. Habitat for Humanity Halton-Mississauga ............................................ 42

5.4.2. Options for Homes ................................................................. 42

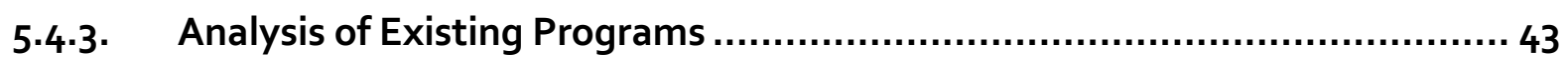

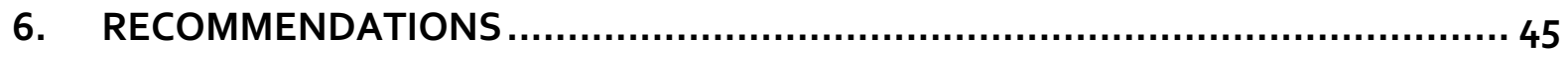

6.1. Recommendation 1 - Vacant Land Inventory .......................................... 45

6.2. Recommendation 2 - Use Public Lands First............................................. 46

6.3. Recommendation 3 - First Time Home Buyers Assistance .......................... 47

6.4. Recommendation 4 - Education for Programs ......................................... 47

6.4.1. Workshops ........................................................................... 47

6.4.2. Resource Tool Easy for Residents to Access........................................ 48

6.5. Recommendation 5 - Incentives for Developers to Build Affordable Housing .. 48

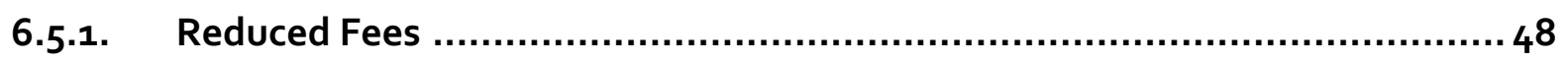

6.5.2. Reduced parking for developments close to transit corridors ...................... 49

6.5.3. Reduced landscaping requirements .................................................... 49

6.6. Recommendation 6 - Secondary Units..................................................... 49

6.7. Recommendation 7- Encourage Wood-frame Apartments in Medium-Density

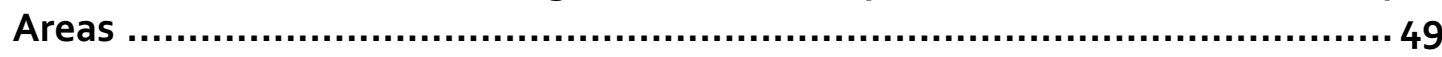

6.8. Recommendation 8 - Focus on Low- and Moderate-income Households ........ 50

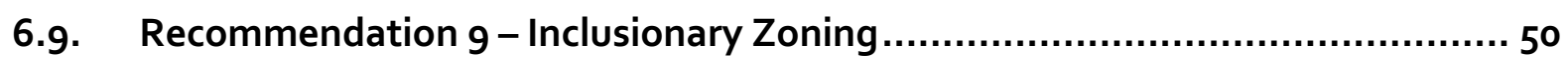

6.10. Recommendation 10 - Limited Equity Cooperatives ................................... 50

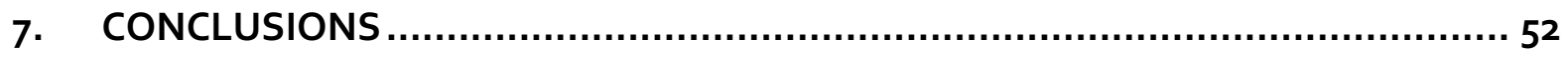

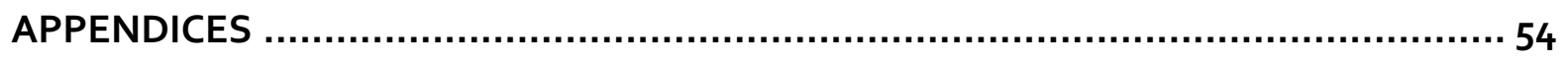

Appendix A: Tables for Core Housing Need ............................................... 54

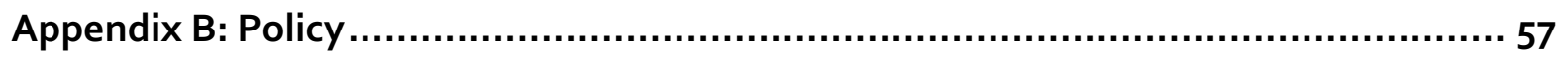

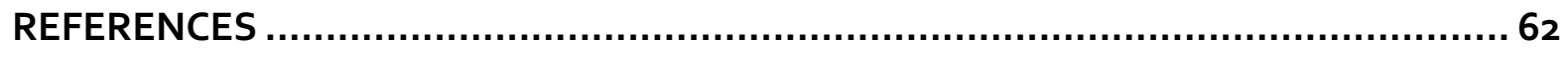

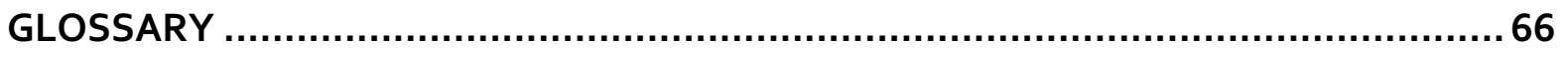


Figure 1 Canadian Homeownership Rates, 1971 to 2011 Sources: Author's calculation, using data from Statistics Canada, censuses of population, 1971 to 2006 and National household Survey, 2011......7

Figure 2 Housing Price Index 2000 to 2016 Source: Author's Calculations, using data from Teranet and

National Bank of Canada: House Price Index.

Figure 3 Ontario: New Home Market Source: Author's calculations, using data from Housing Market Outlook Ontario Region Highlights, 2016.

Figure 4 Ontario Ownership Rates Sources: Author's calculations, using data from Statistics Canada. 1991. CHASS 1991 cumulative. Ontario.; Statistics Canada. 1996. CHASS 1996 cumulative. Ontario; Statistics Canada. 2001. CHASS 2001 cumulative. Ontario.; Statistics Canada. 2006. CHASS 2006 cumulative. Ontario.; Statistics Canada. 2011. CHASS 2011 NHS. Ontario ...............11

Figure 5 Mississauga: Population (1981-2016) Source: Author's calculations, using data from Statistics Canada. CHASS 1981 cumulative. Census subdivision, Mississauga.; CHASS 1986 cumulative. Census subdivision, Mississauga.; CHASS 1991 cumulative. Census subdivision, Mississauga.; CHASS 1996 cumulative. Census subdivision, Mississauga.; CHASS 2001 cumulative. Census subdivision, Mississauga.; CHASS 2006 cumulative. Census subdivision, Mississauga.; CHASS 2011 NHS. Census subdivision, Mississauga.

Figure 6 Mississauga: Percent of Non-immigrant and Immigrant Population (2001 - 2011) Source: Author's calculation, using available data from CHASS 2001 cumulative. Census subdivision, Mississauga.; CHASS 2006 cumulative. Census subdivision, Mississauga.; CHASS 2011 NHS. Census subdivision, Mississauga. 16

Figure 7 Mississauga: Percent of Immigrant Population that are recent 2001-2011 Source: Author's Calculation, using available data from CHASS 2001 cumulative. Census subdivision, Mississauga.; CHASS 2006 cumulative. Census subdivision, Mississauga.; CHASS 2011 NHS. Census subdivision, Mississauga.

Figure 8 Mississauga Top 6 Visible Minorities (2001-2011) Source: Author's Calculation, using available data from CHASS 2001 cumulative. Census subdivision, Mississauga.; CHASS 2006 cumulative.

Census subdivision, Mississauga.; CHASS 2011 NHS. Census subdivision, Mississauga. ................18

Figure 9 Homeownership Rate Mississauga Source: Author's calculations, using available data from Statistics Canada. CHASS 1981 cumulative. Census subdivision, Mississauga.; CHASS 1986 cumulative. Census subdivision, Mississauga.; CHASS 1991 cumulative. Census subdivision, Mississauga.; CHASS 1996 cumulative. Census subdivision, Mississauga.; CHASS 2001 cumulative. Census subdivision, Mississauga.; CHASS 2006 cumulative. Census subdivision, Mississauga.; CHASS 2011 NHS. Census subdivision, Mississauga. 19

Figure 10 Mississauga Housing Affordability Issues (2011) Source: City of Mississauga. Affordable Housing Program - Housing Gap Assessment.................................................................. 24

Figure 11 Mississauga Housing Affordability Issues by Household Type (2011) Source: City of Mississauga. Affordable Housing Program - Housing Gap Assessment...................................25

Figure 12 Mississauga Deep Housing Affordability Issues by Household Type (2011) Source: City of Mississauga. Affordable Housing Program - Housing Gap Assessment.................................... 26

Figure 13 Mississauga Supply of Dwellings by Type (2011) Source: City of Mississauga. Affordable

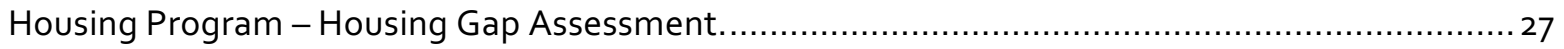

Figure 14 Mississauga Ownership Housing Affordability Source: City of Mississauga. Affordable Housing

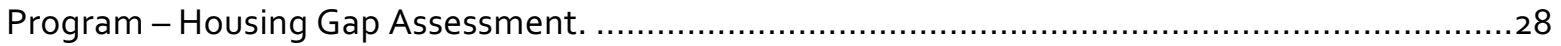

Figure 15 Mississauga Rental Housing Affordability Source: City of Mississauga. Affordable Housing

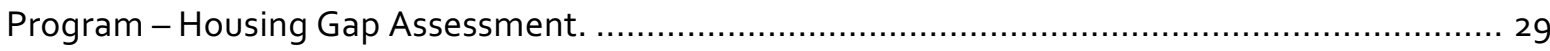

Figure 16 Mississauga Housing Demand and Supply Continuum Source: City of Mississauga. Affordable Housing Program - Housing Gap Assessment. 31 


\section{LIST OF TABLES}

Table 1 Existing \& Future Housing Unit Potential Source: Hemson Consulting Ltd., based on City of Mississauga data

Table 2 Percent Change in number of Sales by Category and by Price Range Source: Author's calculations, using data from Mississauga Real Estate Board, Sales by Price Range and Mississauga Real Estate Board, Sales by Category.

Table 3 Canada: Core Housing Need Source: CMHC (Census-based and NHS-based housing indicators and data), Statistics Canada (Census of Canada, National Housing Survey)

Table 4 Ontario: Core Housing Need Sources: CMHC (Census-based and NHS-based housing indicators and data), Statistics Canada (Census of Canada, National Housing Survey) ...............................5 6

Table 5 Annual Minimum New Housing Unit Targets in Peel and Mississauga Source: Region of Peel Official Plan 


\subsection{Introduction}

Homeownership is one of the largest purchases a household will make in its lifetime. It not only provides a basis for securing a home and accumulating assets, it is often the main form of savings (Painter \& Redfearn, 2002; Hou, 2010; McKee, 2012; Begley, 2017). Along with wealth-building, homeownership has associated societal benefits relating the physical appearance of the property, creating a better environment for the surrounding area (Painter \& Redfearn, 2002), improved quality of life and contributes to local economies. In many places, homeownership is a symbol of social acceptance and a marker of membership in mainstream society (McKee, 2012). It is said to be "the cornerstone of a vibrant society" (Swidler, 2011). Homeownership is a complex concept and may not fit the needs of every household; like anything, there are benefits and contraints that may attract or deter households from becoming homeowners.

This paper explores literature relating to housing affordability and the concerns associated with it, including affordable homeowership and affordable rental. However, this paper specifcally focuses on affordable ownership in Mississauga. It explores homeownership, through factors that may influence tenure choices, affordable housing options as well as the importance of affordability. This paper looks at the housing trends in the City of Mississauga over the past 20 years, focusing on changes in tenure, population growth and employment growth. Using Mississauga as a case study, affordable housing options currently available both on a governement and non-profit level is explored as well as the potential for other options within the municipality. Through understanding Mississauga's history, housing policies and the city's affordability issue, the document is intended to provide recommendations to alleviate increasing unaffordability. The recommendations for this paper are tailored to fit the City of Mississauga but may also be altered to apply to the needs of other municipalities in the Greater Golden Horseshoe Area (GGHA) that face similar issues.

Overall, this document is intended to bring an understanding to affordable housing and address that affordable homeownership is an important part of creating vibrant and sustainable communities and offer recommendations that can guide the implementation of affordable housing initiatives. 


\subsection{Importance of Research}

Housing is an important aspect of life; adequate, affordable and suitable housing is essential for ensuring the quality of life of all citizens. Understanding the fundamental issues associated with housing, and particularly homeownership, is important in the planning realm. Planning plays a vital role in representing those that cannot represent themselves, and a need to influence policy plans for future populations is crucial in ensuring high quality of life for everyone. This research is intended to inform readers of the affordability issues associated with homeownership and housing in general. It hopes to enlighten readers on the programs and policies that currently exist and find gaps where improvements can be made. This paper uses Mississauga as a case study example because it is a flourishing municipality within the Greater Golden Horseshoe Area (GGHA). These recommendations are intended to guide Mississauga and other municipalities around the GGHA to alleviate the housing affordability issue. 


\subsection{Literature Review}

Homeownership is often the largest investment a household will make in its lifetime (Painter \& Redfearn, 2002) and does not come without associated risks. Although owning a home is more secure than renting, in many ways, it is still not $100 \%$ secured. Homeownership is both an investment and a consumable good for the owner, and solely a consumable good for non-owners within a household (Hou, 2010). It is an asset and a public good because owners and non-owners participate in consuming the services provided by the actual house (shelter) and by the surrounding community (amenities in the neighbourhood) (Hou, 2010). Homeownership is a social benefit and is often the greatest source of savings (Painter \& Redfearn, 2002; Hou, 2010; McKee, 2012; Begley, 2017). It is not just an investment and an accumulation of personal wealth but, "is a financial resource families can tap into across the life cycle to meet their welfare needs" (McKee, 2012). It can also generate "neighborhood benefits related to property upkeep, public safety, school quality, and the like" (Painter \& Redfearn, 2002).

The literature has continuously associated homeownership with reduced mobility (Aaronson, 2000; Dietz \& Haurin, 2003; Phang, 2010). Higher moving costs is a result of reduced mobility and thus, owners tend to remain in the same neighbourhood longer than renters (Green \& White, 1997). This may encourage owners to take greater responsibilities for their families and surrounding community (Green \& White, 1997). This greater responsibility is brought on by the stake that homeowners have in their homes (Green \& White, 1997). Homeowners want to ensure that their investment maintains attractiveness and when they do decide to move or sell that capital losses are avoided (Green \& White, 1997). Aaronson (2000) discussed how low mobility neighbourhoods have positive effects on children and their learning. Homeownership also suggests a more stable home environment, contributing to the well-being of the children living in the homes (Green \& White, 1997). This can be referred back to the concept that homeownership is not just an investment but a consumerable good that contributes to overall public good. Green \& White (1997) suggest that children of homeowners are more likely to stay in school, achieve a higher level of education and can contribute to the future of the wider society. Moreover, homeownership contributes to the viability of communities, as neighbourhoods with a lower homeownership rate generally have less amenities (Painter \& Redfearn, 2002). 
Homeownership comes with some degree of risk, especially since it is a huge invesment and accounts for the majority of a household's investment portfolio, leaving little room for diversity, increasing overall risk (Painter \& Redfearn, 2002; Phang, 2010; Sekkat \& Szafarz, 2011). Moreover, purchasing a house requires a large upfront cost, and one of the biggest barriers that prohibit households from moving into ownership from the rental market is access to this capital (or down payment) (Painter \& Redfearn, 2002; Dietz \& Haurin, 2003; Phang, 2010). Some literature suggest evidence that young people's life-cycle consumptions are distorted by down payment saving behaviours (Dietz \& Haurin, 2003; McKee, 2012). Without assistance, the rising house prices and increased amount required for down payment will continue delaying entrance into the ownership market (McKee, 2012). Rising house prices and large down payment requirements are not the only factors contributing to delayed homeownership among younger generations. Literature suggests that young people are also delaying homeownership due to lengthening education, high youth unemployment, increasing levels of debt and restrictied access to welfare benefits (McKee, 2012). In the UK, the average age of entering homeownership without parental assistance is 37 years old (McKee, 2012). Financial assistance from relatives has become necessary in helping young people achieve homeownership (McKee, 2012).

Housing choices, are no longer truly choices, they are shaped by wider societal structures, which impact available tenure options for individuals and families (McKee, 2012). The rising prices of housing has impacted the ability of individuals and families to move from renting to owning in a timely manner. While at equilibrium, owning is preferred over renting, the large investment of homeownership is associated with a high risk. The choice of tenure is associated with risk appetite and behaviours of certain households (Sekkat \& Szafarz, 2011). For example, wealthy households may have a higher risk appetite because they may have some capital to fall back as a safety net, whereas lower income households may not be as risky because there is no safety net if they default on their mortgage. Literature suggests that policy should guide this issue and create options to facilitate homeownership for younger generations, to avoid the creation of a lost generation (McKee, 2012). The behaviours of delayed homeownership and renting are behaviours that are brought on by barriers and inabilities to enter ownership, posing an affordability issue.

Homeownership is an important part of society and contributes to the quality of life. It also has economic benefits and contributes to the local economy. The housing sector plays a vital role in the economy, in many developed countries (Rolnik, 2013). Property tax is one of the largest revenues 
streams of municipalities and homeownership can contribute to increaseing this revenue. Property tax is comprised of the assessed property value and tax rates established by the municipality. It contributes to the local municipal revenue, the regional revenue and contributes the province of Ontario for educational purposes (City of Mississauga, n.d.). In Mississauga, for example, the city receives 31\% of the total property tax, $46 \%$ goes to the Region of Peel and $23 \%$ goes to the Province for education. Regardless of the tenure of residents, the property tax will be received by the municipality. However, increased homeownership contributes to increased investment in the neighbourhood and responsibility of the home, which can contribute to the attractiveness of the neighbourhood and potentially add to the overall property value.

Hulchanski (2006) discusses the importance of homeownership as households' age. Homeowners have something to draw from as they age, they can downsize and sell their larger home for something smaller, freeing up money, whereas long-term renters do not have anything to draw from as they age (Hulchanski, 2006). The Canadian government has a long history is shaping the way the current housing system functions, and largely focus on the homeownership sector (Hulchanski, 2006). If it were not for federal policies and programs, Canadian homeownership rates would be much lower (Hulchanski, 2006). The growing gap between rich and poor has been particularly apparent in the housing market in Canada. Households are divided into two distinct groups of housing consumers (Hulchanski, 2006). In 1996, the federal government transferred housing responsibilities to provinces and territories, which meant that federal funding was withdrawn, and the financial burdens were downloaded to provincial taxpayers (Hulchanski, 2006). However, in terms of ownership, the jurisdictional discussion is generally lacking and all three levels of government jump at opportunities to assist owners (Hulchanski, 2006). All levels of government privilege homeowners; the federal government's housing activities through budgetary spending programs or tax expenditures are considered incentives and entitlements as rights associated with investing in and owning a home (Hulchanski, 2006). In Canada, there is significant benefit in being a homeowner as owner-occupied houses are exempt from capital gains taxes, which generates about $\$ 3.7$ billion annually (Hulchanski, 2006). This large subsidy is only offered to homeowners and there is no equivalent subsidy available for private renters or rental housing investors (Hulchanski, 2006). The reason for the federal government focus on homeowners is provide and produce high and relatively stable levels of housing starts. This contributes to overall economic growth as well as provide many well-paying jobs (Hulchanski, 2006). 
The following section describes the role of the Canada Mortgage and Housing Corporation, discusses information about homeownership rates, and explores the housing outlooks in Canada, Ontario and the GTA. This section concludes with identifying housing affordability issues.

\subsection{Housing Market}

\subsubsection{Canada}

The Canada Mortgage and Housing Corporation $(\mathrm{CMHC})$ is Canada's authority on housing and are responsible for helping Canadians meet their housing needs (Canada Mortgage and Housing Corporation, 2017). CMHC contributes to the stability of the housing market and the financial systems in the country, they provide services which include mortgage loan insurance, first nation housing, securitization, affordable housing, policy and research as well as provide Canadians with information so that they can make informed decisions (Canada Mortgage and Housing Corporation, 2017). CMHC was established in 1946 to house returning war veterans and to lead Canada's housing programs (Canada Mortgage and Housing Corporation, n.d.). The main purpose of $\mathrm{CMHC}$ was to administer the National Housing Act, the Home Improvement Loans Guarantee Act as well as provide discounting mechanisms for loans and mortgage companies (Canada Mortgage and Housing Corporation, n.d.). CMHC has had a long history of serving to improve the lives of Canadians through housing.

Since 1971, homeownership rates have continued to increase. Figure 1 represents the homeownership rate from census data collected between 1971 to 2011. Increasing ownership can partly be attributed to rising incomes in Canada (Painter \& Redfearn, 2002), but also factors such as low interest rates and a loosening of credit restrictions which have allowed household's to increase their borrowing capacities (Cheung, 2014). However, the ability of a household borrow is not indicative of an affordable or sustainable market. Despite the high ownership rate, the health of housing in Canada has been deteriorating rapidly. Housing price increases have surpassed increases in household income, which has contributed to the difficultly of households entering the ownership market (Cheung, 2014). "Ownership rates do not capture either the size or quality of housing" that are occupied by households (Swidler, 2011). According to $C M H C$, if households do not meet any of the three housing standards, they are considered in 'core housing need', these include, affordability, suitability and adequacy (Canada Mortgage and Housing Corporation, 2016). Core Housing Need is defined as households falling below at least one of these standards and spending more than $30 \%$ of before tax income on housing (Canada Mortgage and Housing Corporation, 2016). 


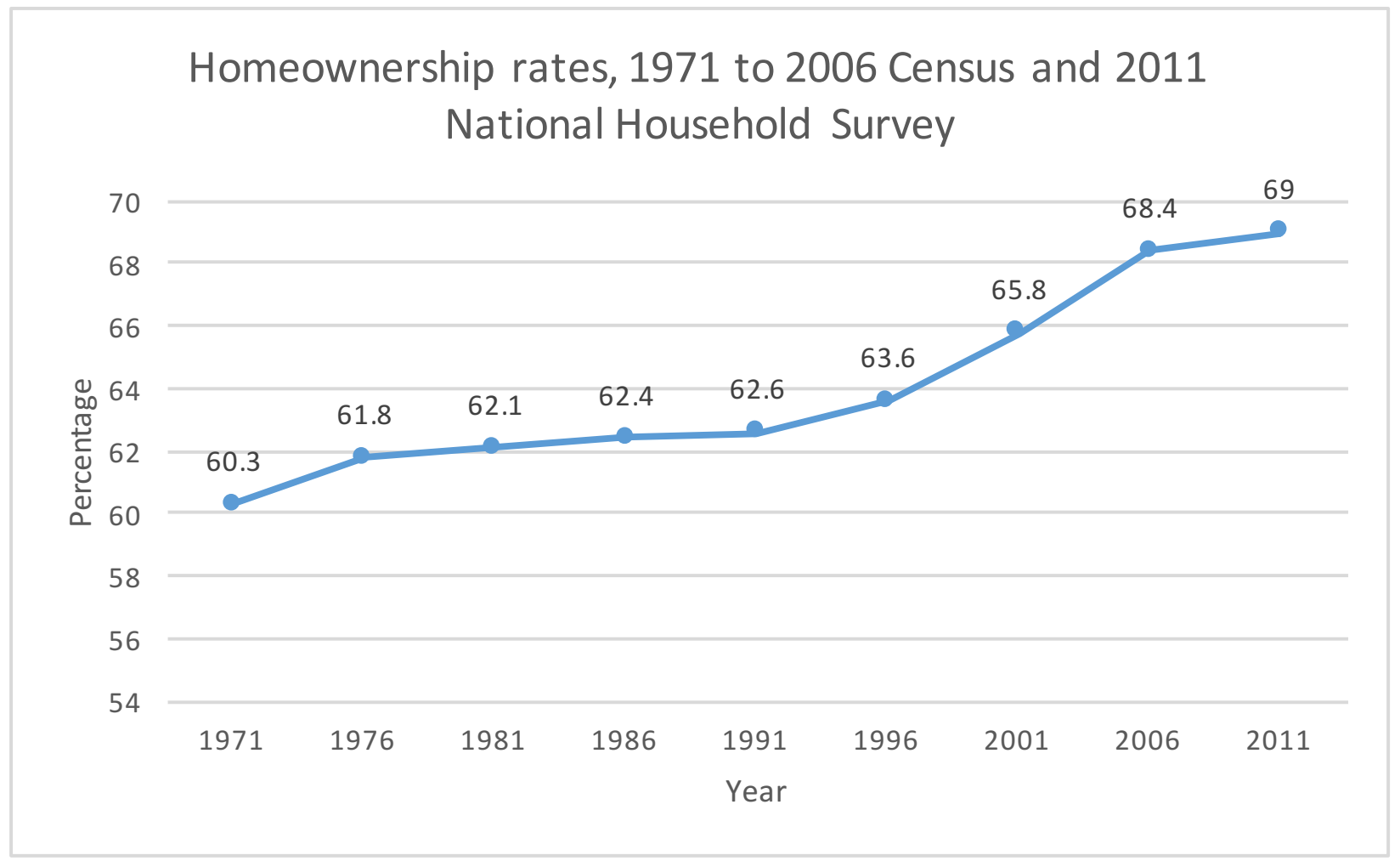

Figure 1 Canadian Homeownership Rates, 1971 to 2011

Sources: Author's calculation, using data from Statistics Canada, censuses of population, 1971 to 2006 and National household Survey, 2011

The Housing Market Outlook Report released by $\mathrm{CMHC}$ reflect forecasts and data up until the end of September 2016. This report, the Housing Market Outlook Report, 2016 looks at the economic, financial and housing market conditions in Canada as well as forecast data for the the coming years. Overall, housing starts in the country have been declining slightly from 2015, and will continue declining through 2017 before stabilizing in 2018 (Canada Mortgage and Housing Corporation, 2016). The decline in housing starts reflects a decline in new supply throughout the country. In 2016, there was an increase in Multiple Listing Service (MLS) resales, but due to changing demographics across Canada, the number of resales is expected to decline through 2018 (Canada Mortgage and Housing Corporation, 2016). Understanding the shift in supply both new and resale is important in understanding housing affordability as well as access to affordable housing for existing and potential homeowners. As supply and demand shift, overvaluation becomes a concern. Overvaluation refers to the purchase price exceeding the fundamental value that a house may be assessed as (Investopedia, 2017). This has contributed to the affordability issue as many houses are being purchased over asking price. The repeat sales index refers to the changing prices for the same piece of real estate (Investopedia, 2017). This is an 
accurate indication of changing housing prices and eliminates potential outliers that potentially skew results. Figure 2 represents the Housing Price Index in Toronto between 2000 and 2016, this index is created by Teranet and the National Bank of Canada and uses repeat sales to calculate the index ${ }^{1}$. The index shows that prices have continuously increased since 2000, with a slight decline between 2007 and 2008. The largest changes over the 16-year period occurred between 2010 and 2011 , about a 10\% increase, between 2014 and 2015, about a 10\% increase and finally between 2015 and 2016, about 20\% increase. Over the course of the 16-year period, housing prices in Toronto have increased by $187 \%$.

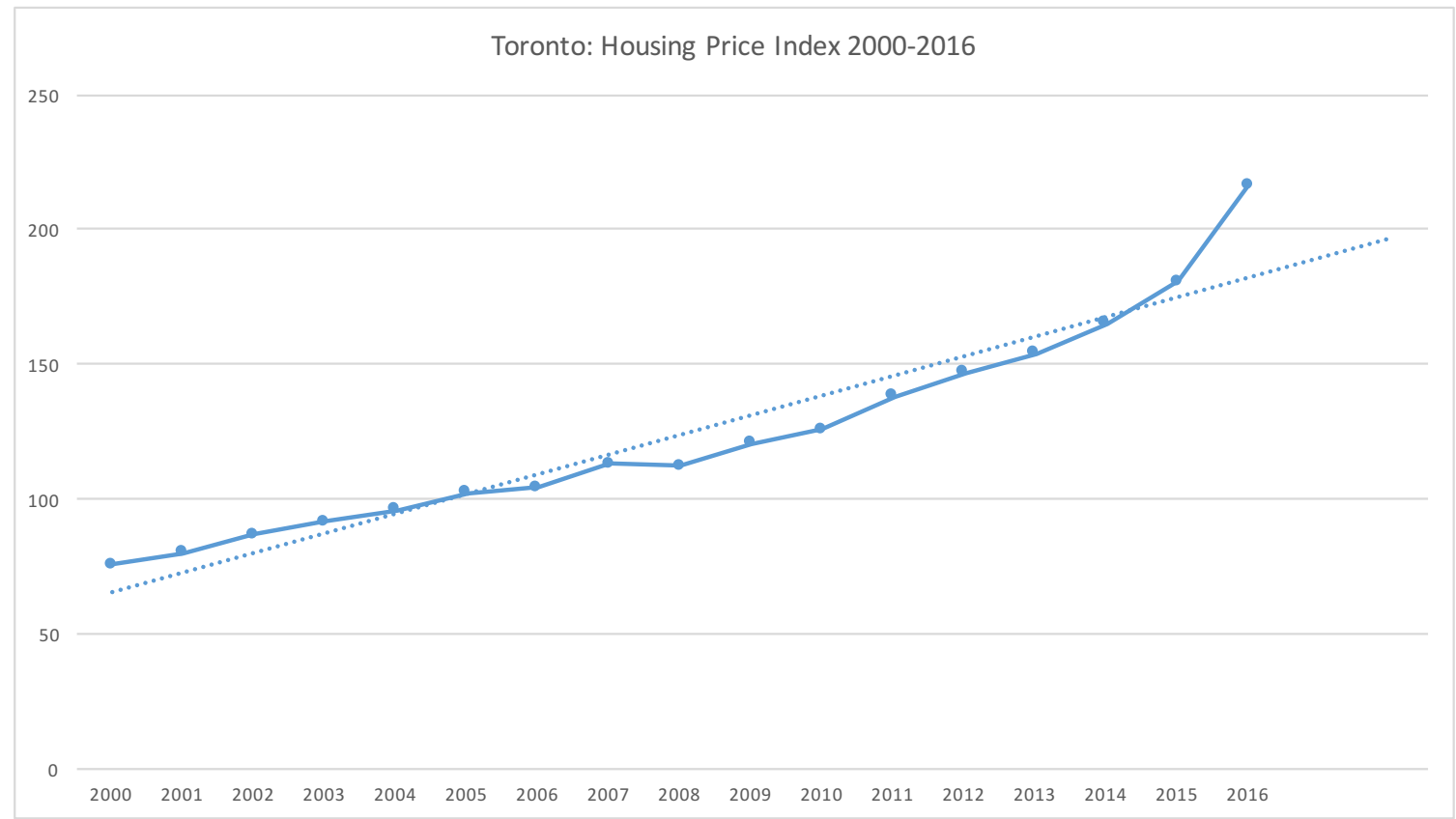

Figure 2 Housing Price Index 2000 to 2016

Source: Author's Calculations, using data from Teranet and National Bank of Canada: House Price Index.

Debt-to-income (DTI) refers to the amount of debt acquired by a household compared to the overall household income. This measurement is preferred over loan-to-value (LTV) because it is a better indication of whether or not households can afford their home. LTV simply measures the loan amount in comparison to the value of the home, whereas DTI ratio measures how much debt a household has compared to what is earned. The DTI ratio Canada reached a historic peak of $167.6 \%$ in the fourth quarter of 2016 (Canada Mortgage and Housing Corporation, 2016). This poses a significant risk to households as they are more vulnerable to major increases in interest rates and unemployment. The DTI ratio is a significant concern to the sustainability of homeownership, as an increase in interest rates

\footnotetext{
${ }^{1}$ Due to lack of available data, the figure indicates house prices in Toronto, as they are not available for Canada, Ontario or Mississauga.
} 
and/or unemployment could increase the risk of making debt payments and could force households to liquidate assets such as their homes (Canada Mortgage and Housing Corporation, 2016). Moreover, resulting in a decline of housing prices and housing market activity across the country (Canada Mortgage and Housing Corporation, 2016). LTV is also an important measure; it indicates the amount of debt a household is takes against the value of the home. The higher the LTV, the higher a households' DTI ratio. This means that regulations need to be implemented in order to ensure the stability of households in homeownership, if factors such as interest rates and unemployment increased.

As of October 3, 2016 the Canadian Government implemented a new mortgage regulation to ensure that borrows taking on more than $80 \%$ loan-to-value (LTV) will be able to make loan payments if interest rates increase (Canada Mortgage and Housing Corporation, 2016). This regulation was implemented to increase the stability of the housing market to ensure that households would be able to make payments and remain in their homes. Mortgage rates are expected to increase modestly over the next few years and this new regulation includes new eligibility rules for both high ratio insured mortgages (loan-to-value more than 80\%) and for low ratio insured mortgages (loan-to-value less than 80\%) (Canada Mortgage and Housing Corporation, 2016). All high ratio borrowers will have to meet a higher standard of debt servicing to ensure that payments can be made if mortgage rates increase after the 5 -year term (Canada Mortgage and Housing Corporation, 2016). This new regulation is expected to affect about $5-10 \%$ of all prospective home buyers during the first year of implementation (Canada Mortgage and Housing Corporation, 2016). This regulation is important in ensuring the stability of homeownership as well as ensuring that increased DTI ratios will not be detrimental to the Canadian housing market.

\subsubsection{Ontario}

Every province in Canada has unique trends within the housing market. Ontario has experienced a significant increase in average housing prices compared to Canada as a whole (Canada Mortgage and Housing Corporation, 2016). Since 2014, Ontario's economy has outpaced national growth, but should converge closer to the national average by 2018 (Canada Mortgage and Housing Corporation, 2016). Figure 3 displays the actual (2013-2015) and forecasted (2016-2018) Ontario New Home Market. This 
New Home Market is indicative of a shift in supply, from single-detached homes to apartments ${ }^{2}$. The number of starts are expected to slow between 2017 and 2018, due to rising debt loads in Ontario. Both Ontario and British Columbia constitute for about two thirds of all national resales. Ontario and British Columbia's housing markets are dramatically different than the rest of Canada, mainly due to major metropolitan centres and more economic activity.

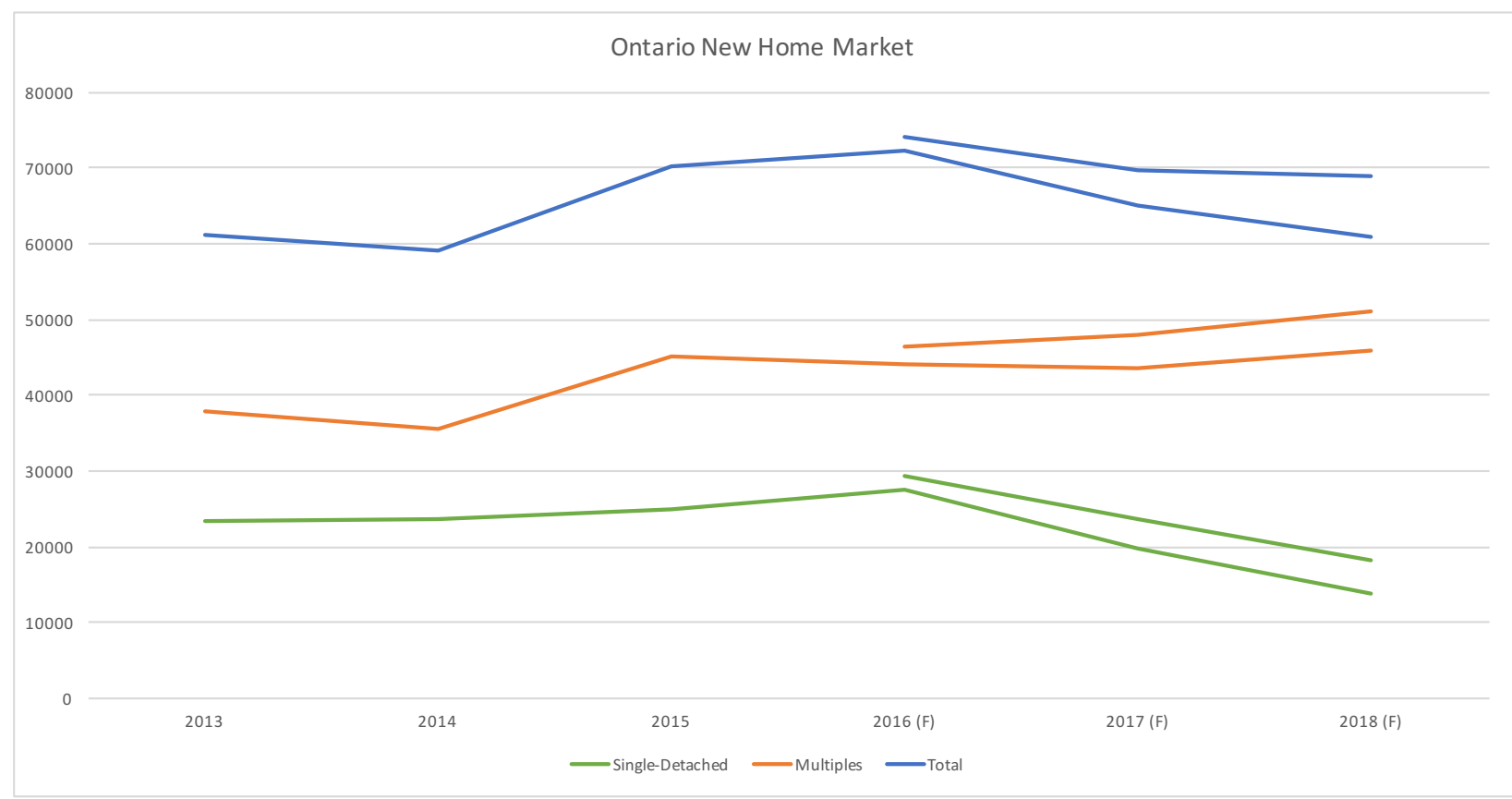

Figure 3 Ontario: New Home Market

Source: Author's calculations, using data from Housing Market Outlook Ontario Region Highlights, 2016.

Housing between southwestern Ontario and the GTA is a lot different than Northern and Eastern Ontario. Growth in southwestern Ontario and the GTA continues to increase, as does the cost of living. On the contrary, Northern and Eastern Ontario face economic conditions that restrain housing activity. Overall Ontario home prices will continue to increase but at a slower rate by 2018 (Canada Mortgage and Housing Corporation, 2016). Despite the increasing house prices and decreasing starts for Ontario, homeownership rates have continued increasing since 1991. Figure 4 shows the increase in ownership in Ontario from 1991 to 2011 based on census data.

\footnotetext{
${ }^{2}$ Repeat-sales indices are unavailable for Ontario. It would have been used to show accurate price changes in new houses.
} 


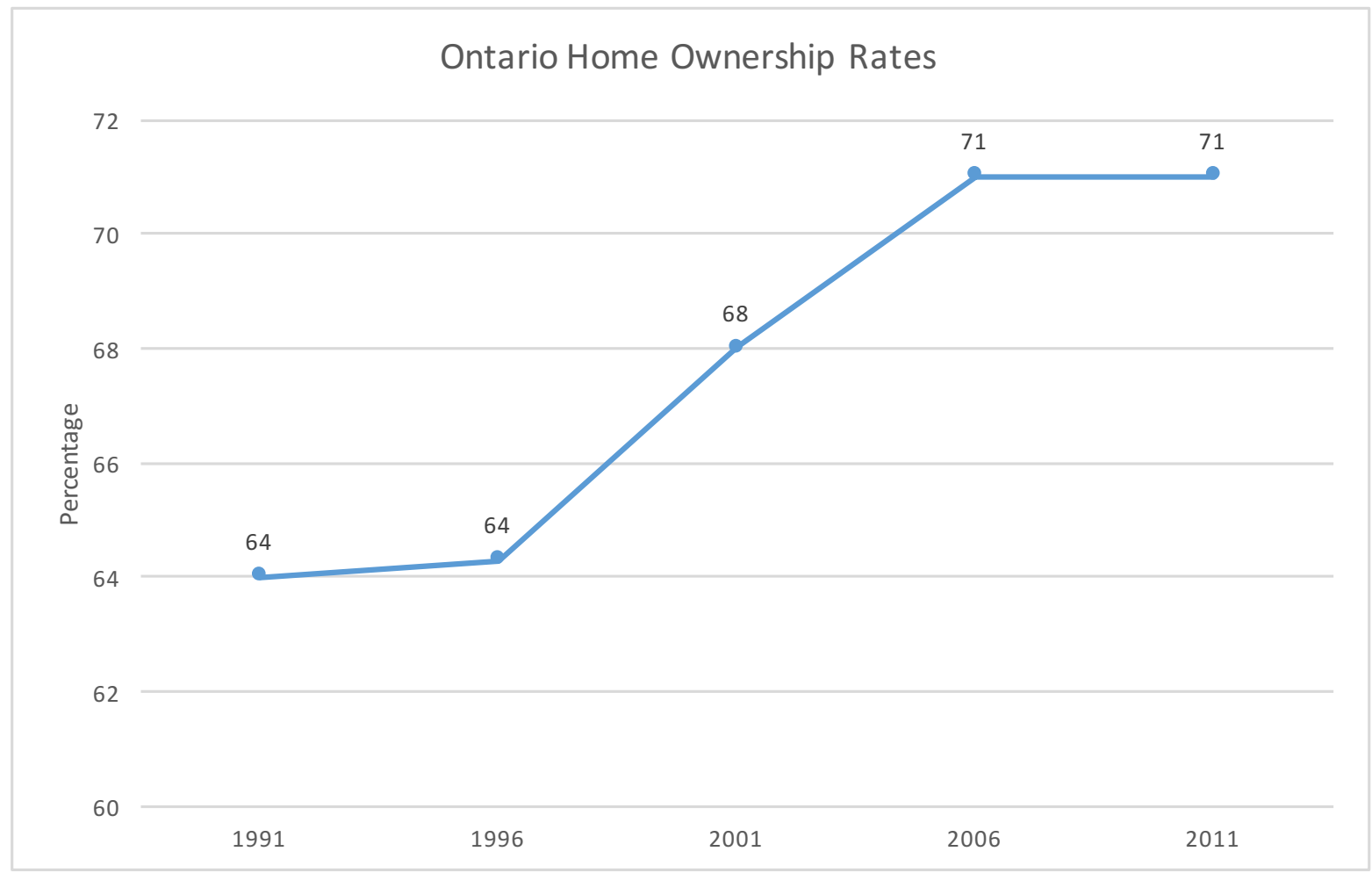

Figure 4 Ontario Ownership Rates

Sources: Author's calculations, using data from Statistics Canada. 1991. CHASS 1991 cumulative. Ontario.; Statistics Canada. 1996. CHASS 1996 cumulative. Ontario; Statistics Canada. 2001. CHASS 2001 cumulative. Ontario.; Statistics Canada. 2006. CHASS 2006 cumulative. Ontario.; Statistics Canada. 2011. CHASS 2011 NHS. Ontario

\subsection{Affordability Issue}

The Greater Golden Horseshoe Area is facing affordable housing issues. Shift in supply and demand, and municipal demographics and age structure have all contributed to this issue. The Growth Plan for the Greater Golden Horseshoe is changing the course of housing supply as the policy intends to intensify already built-up areas and direct growth within the Greater Golden Horseshoe, putting pressure on the supply of single-detached houses. Finding affordable housing for ownership has been increasingly difficult, the cost of purchasing a home is rising and the rate in which homes are selling is increasing pressures on potential home buyers. Households are spending more of their disposable income on shelter costs, many exceeding $30 \%$ of income increasing the risk of households falling under core housing need. CMHC's housing standards evaluate three factors to determine whether or not a household is in 'Core Housing Need'. A household is defined as in 'Core Housing Need' if it,

Does not meet one or more of the adequacy, suitability or affordability standards and it would have to spend $30 \%$ or more of its before-tax income to access local housing that meets all three standards (Canada Mortgage and Housing Corporation, 2014). 
$12.5 \%$ of households (1.6 million) were in Core Housing Need in Canada in 2011, but about 31\% of Canadians are living below the housing standards (Appendix A: Tables for Core Housing Need - table 3) (Canada Mortgage and Housing Corporation, 2014).

Demographic and social trends have increased the percentage of one-person and lone-parent households (Canada Mortgage and Housing Corporation, 2014), which has an affect on housing affordability, both rental and ownership. Household incomes are influenced by type of education and employment, shelter costs differ by geographic location, size of households affect how suitable certain dwellings are for households, and continuous investment in home repairs and renovations can reduce the number of households that live in inadequate housing (Canada Mortgage and Housing Corporation, 2014). Increasing affordable homeownership could contribute to decreased numbers of households in core housing need. Households that are homeowners are less likely to fall below living standards than renters; in Canada in $2011,7.2 \%$ of homeowners compared to $29.6 \%$ of renters were in core housing need (Appendix A: Tables for Core Housing Need - table 3). The money spent on shelter for homeowners is an investment and contributes to increasing the net wealth of the household. Economic factors including low interest rates, availability of relatively cheap credit, strong economic growth, increases in commodity prices have contributed to rising house prices in places like Canada (Cheung, 2014). Many households that traditionally could become homeowners are remaining as renters because they cannot obtain the down payments required to purchase a home, further increasing the gap between renters and homeowners. The cost of owning a home compared to renting has increased well above the long term average (Cheung, 2014).

Housing affordability is important because "housing is a major contributor to economic growth, social stability and household wealth and indebtedness" (City of Mississauga, 2016). Housing contributes to economic growth directly through the construction sector and indirectly through other sectors such as manufacturing, finance, real estate and insurance, and forestry (City of Mississauga, 2016). For every $\$ 1$ invested in housing, the local Gross Domestic Product (GDP) increases to $\$ 1.40$, according to the Federation of Canadian Municipalities (City of Mississauga, 2016). Additionally, investment in housing can increase employment (City of Mississauga, 2016). Altus Group found that 10,000 housing starts resulted in $\$ 1.8$ billion in production in the construction sector and created 19,300 jobs (City of Mississauga, 2016). Affordable housing matters because it has social impacts that are "directly linked to health, education and household wealth" (City of Mississauga, 2016). Households that secure housing 
increase the likelihood of being in better health, perform better in school, and have more personal wealth (Green \& White, 1997; City of Mississauga). The availability of affordable housing in a community increases the capacity of businesses to sustain a stable workforce (City of Mississauga, 2016). Affordable housing in a community will attract households in all stages of life, contributing to a diverse and vibrant community (City of Mississauga, 2016). Affordable housing is also important in reducing homelessness. The lack of affordable housing can lead to homelessness as more households are at risk of losing their homes (City of Mississauga, 2016). Increasing affordable homeownership contributes to local economies, increases the quality of life in families and individuals as well as results in savings for all levels of government (City of Mississauga, 2016). According to the City of Mississauga's Affordable Housing Program - Housing Gap Assessment report, "every \$10 spent on housing and supports for chornically homeless individuals results in \$21.72 in savings related to health care, social supports, housing and involvement with the justice system" (City of Mississauga, 2016). This section recognized that there is an affordability issue, as well as a need to improve affordablility. It also acknowledged the importance of housing affordability to local economies and overall quality of life for individials and families. 


\section{STUDY AREA: MISSISSAUGA}

This paper examines Mississauga's housing affordability issues, specifically pertaining to homeownership and provides ways to reduce the increasing unaffordability. Mississauga is a city located within the Greater Golden Horseshoe Area (GGHA) and is in the Greater Toronto Area (GTA) sharing a border with the City of Toronto. The municipality has a long history of settlement, housing and has transformed into a vibrant urban area. This section examines the housing trends in Mississauga, including tenure and future growth as well as introduces the affordability issues that the city currently faces.

\subsection{History}

Mississauga is situated on Lake Ontario, with the City of Toronto to the east and City of Oakville to the West. It is located in the Greater Toronto Area, which is in the Greater Golden Horseshoe Area (Ministry of Municipal Affairs and Housing, 2016). This location is a prime location for settlement as it is in the heart of the Great Lakes, within close proximity to the United States and is among the most vibrant, thriving and multicultural economies the world (Ministry of Municipal Affairs and Housing, 2016). Mississauga is the $6^{\text {th }}$ most populous cities in the country and is an important part of the Ontario economy. Figure 5 shows the population growth in the City between 1981 and 2016. Since the 1980's the City's population has been increasing; however, in recent years, population growth has slowed. Between 2011 and 2016 the population increased by only 1.1\% (Statistics Canada, 2016). This section explores the history of the municipality, including demographics and how it has transformed into the city it is today. 


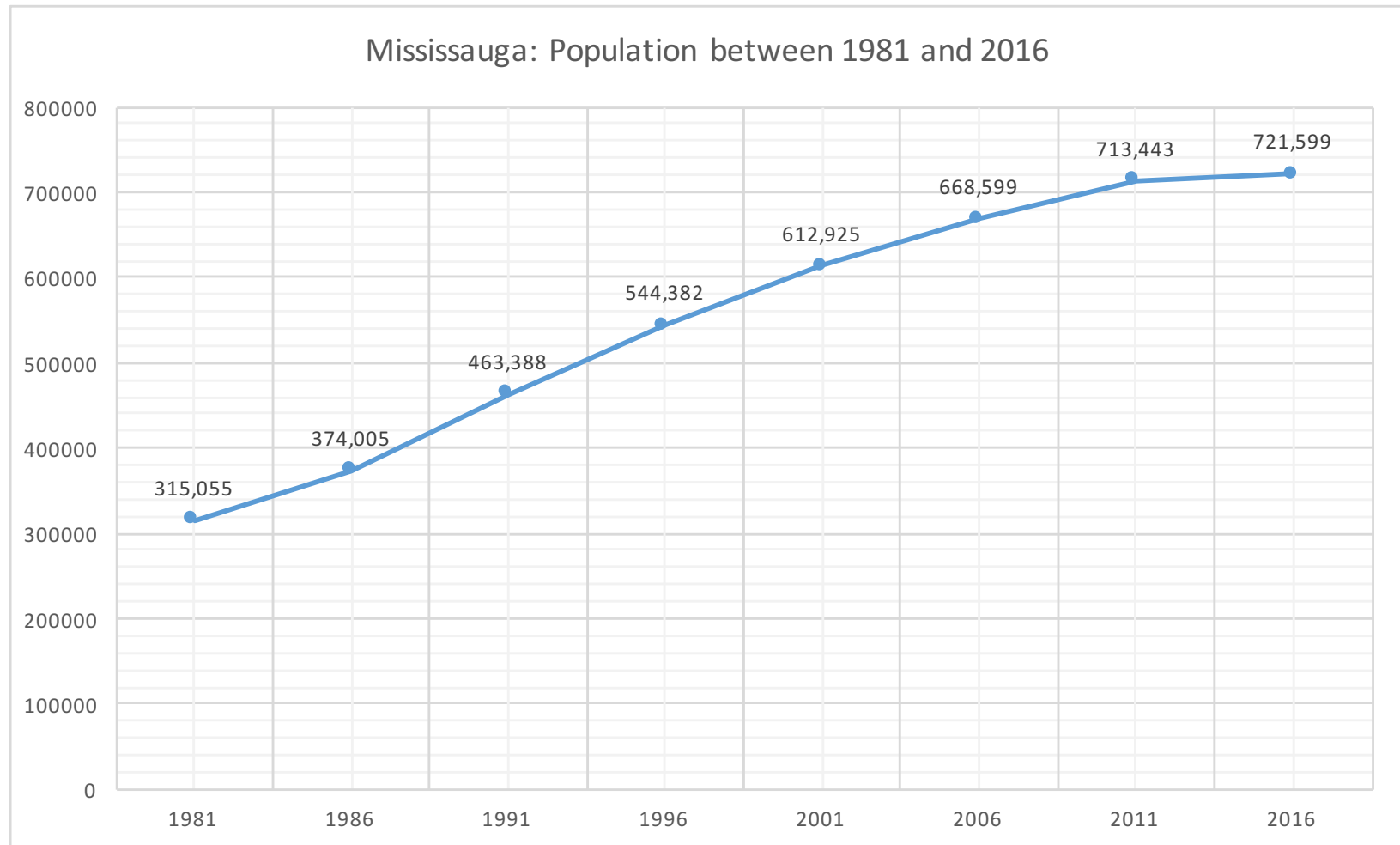

Figure 5 Mississauga: Population (1981-2016)

Source: Author's calculations, using data from Statistics Canada. CHASS 1981 cumulative. Census subdivision, Mississauga.; CHASS 1986 cumulative. Census subdivision, Mississauga.; CHASS 1991 cumulative. Census subdivision, Mississauga.; CHASS 1996 cumulative. Census subdivision, Mississauga.; CHASS 2001 cumulative. Census subdivision, Mississauga.; CHASS 2006 cumulative. Census subdivision, Mississauga.; CHASS 2011 NHS. Census subdivision, Mississauga.

The demographics of Mississauga has changed dramatically throughout history, in the 1950 over $80 \%$ of the population was British but now Mississauga is representative of a multicultural Canadian city. A big part of the City's growth can be attributed to immigrant populations. In 2011, immigrant households made up about $64 \%$ of all households in Mississauga, of these immigrant households about $76 \%$ were homeowners (City of Mississauga, 2016). Figure 6 indicates that since 2001, the portion of the population comprised of immigrants has increased. Recent immigrants refer to the number of immigrants that arrived within the previous 5 years, in 2001, recent immigrants refer to immigrants arriving between 1996 and 2001. 21\% of the immigrants in 2001 were recent immigrants, in 2006, the number of recent immigrants increased by about $24 \%$ and in 2011 this number decreased by about $20 \%$. Figure 7 represents the portion of recent immigrants in relation to the total number of immigrants in Mississauga. This information is important because recent immigrants are among the household types that are most likely to face housing affordability issues. Mississauga's growing diversity could suggest that new household may be likely to face housing affordability issues in the coming years. Additionally, in 2001, visible minorities represented about $40 \%$ of the population, by 2011 , visible 
minorities represented about $54 \%$ of the population. Figure 8 represents the top 6 visible minorities in Mississauga, this figure just gives a sense of how Mississauga is transforming into a vibrant multicultural city.

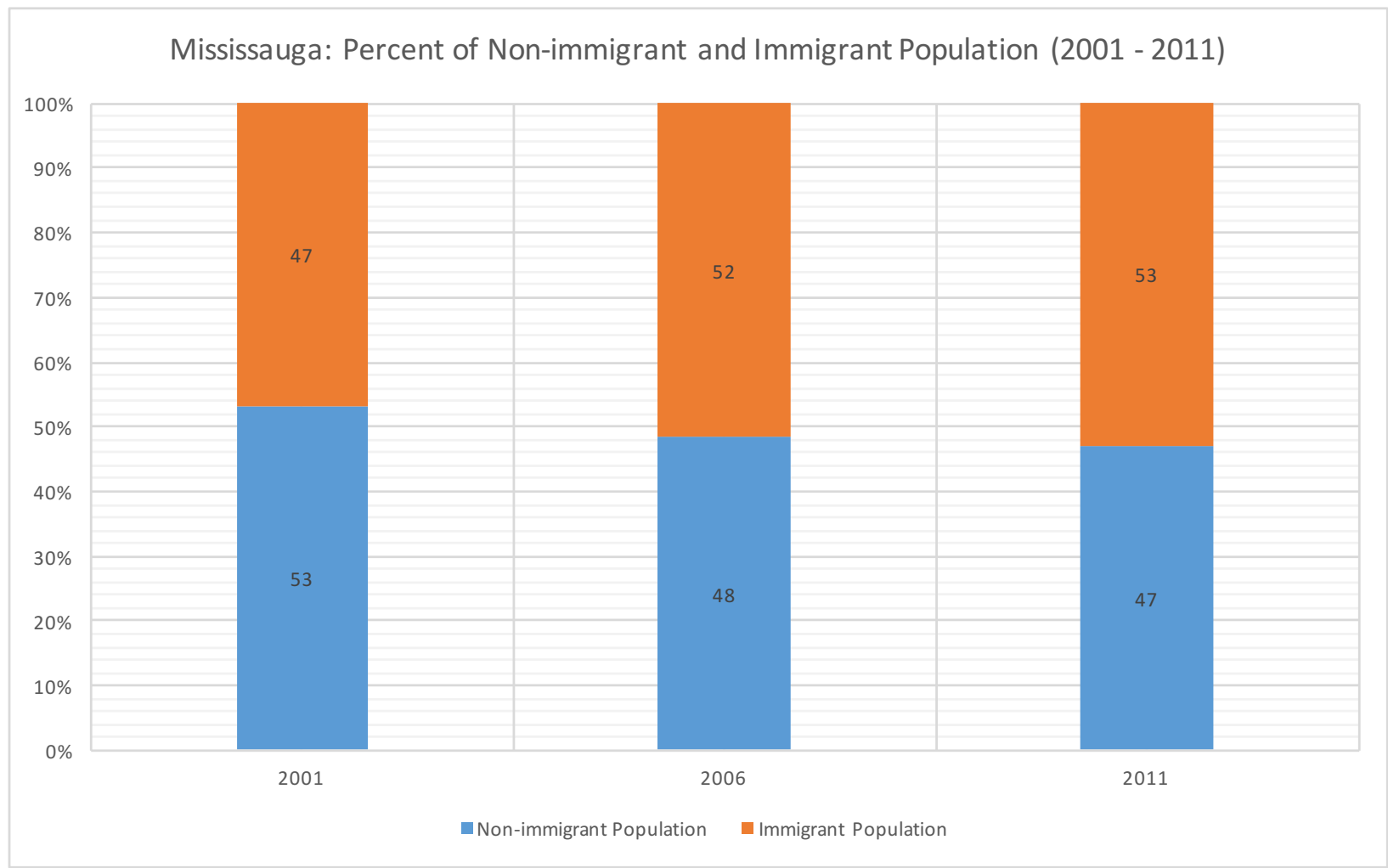

Figure 6 Mississauga: Percent of Non-immigrant and Immigrant Population (2001 - 2011)

Source: Author's calculation, using available data from CHASS 2001 cumulative. Census subdivision, Mississauga.; CHASS 2006 cumulative. Census subdivision, Mississauga.; CHASS 2011 NHS. Census subdivision, Mississauga. 


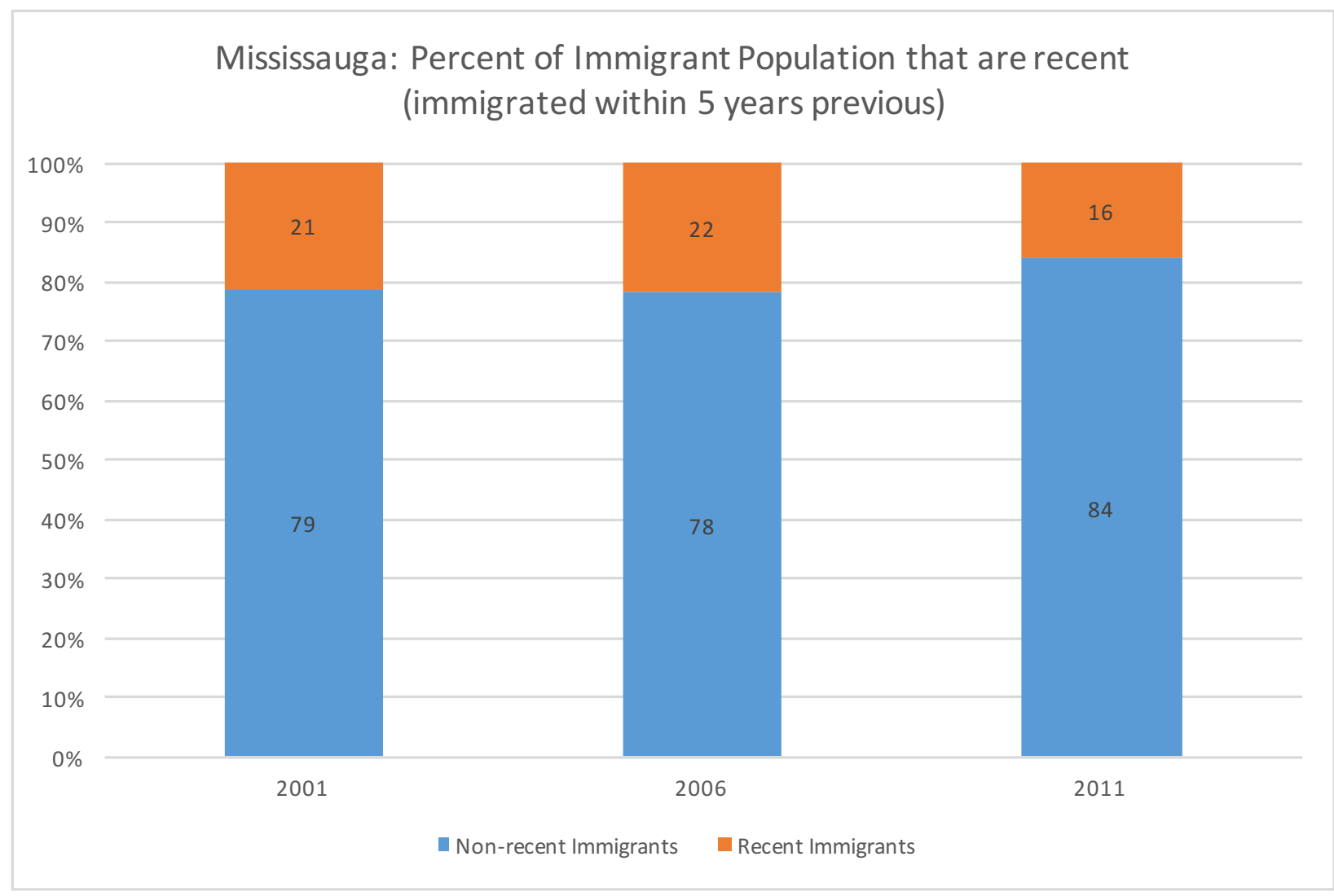

Figure 7 Mississauga: Percent of Immigrant Population that are recent 2001-2011

Source: Author's Calculation, using available data from CHASS 2001 cumulative. Census subdivision, Mississauga.;

CHASS 2006 cumulative. Census subdivision, Mississauga.; CHASS 2011 NHS. Census subdivision, Mississauga. 


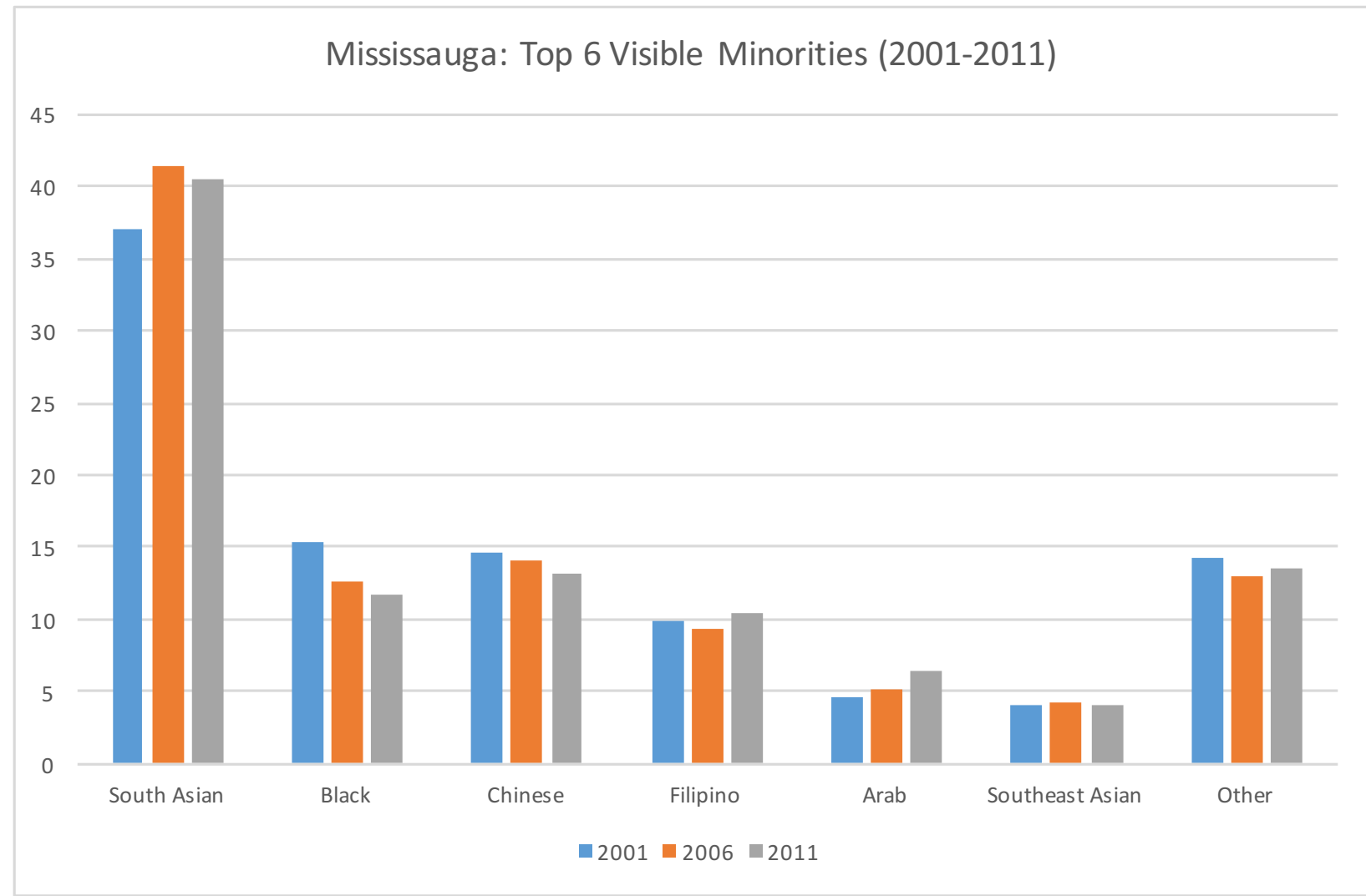

Figure 8 Mississauga Top 6 Visible Minorities (2001-2011)

Source: Author's Calculation, using available data from CHASS 2001 cumulative. Census subdivision, Mississauga.; CHASS 2006 cumulative. Census subdivision, Mississauga.; CHASS 2011 NHS. Census subdivision, Mississauga.

The following sections explore elements of the city in more detail. 3.2 discusses the changes in tenure throughout the City and 3.3 examines growth in Mississauga in recent years and how employment, population and number of dwellings have contributed to the ongoing growth of this vibrant city. $3 \cdot 4$ discusses where the city is headed and introduces documents that may guide the future of Mississauga.

\subsection{Tenure}

Similar to Ontario and the rest of Canada, Mississauga's homeownership rate has continued to increase from 1981 and began plateauing as of the 2011, as shown in figure 9. However, Mississauga's homeownership rates in 2011, were higher by 4 and 6 percentage points than Ontario and Canada, respectively. It will be interesting to see how trends of homeownership continue as house prices increase faster than the increase of household income. The structural type of dwelling in Mississauga is somewhat representative of a suburban city with many low-rise dwellings, however there are areas that represent a more urban lifestyle. The two dominant types of dwellings for all tenure types in 2011 were 
detached (39.1\%) and apartment (35.4\%) (City of Mississauga, 2013). This section focuses on the types of dwelling structures, the age and the tenure of residents in the city.

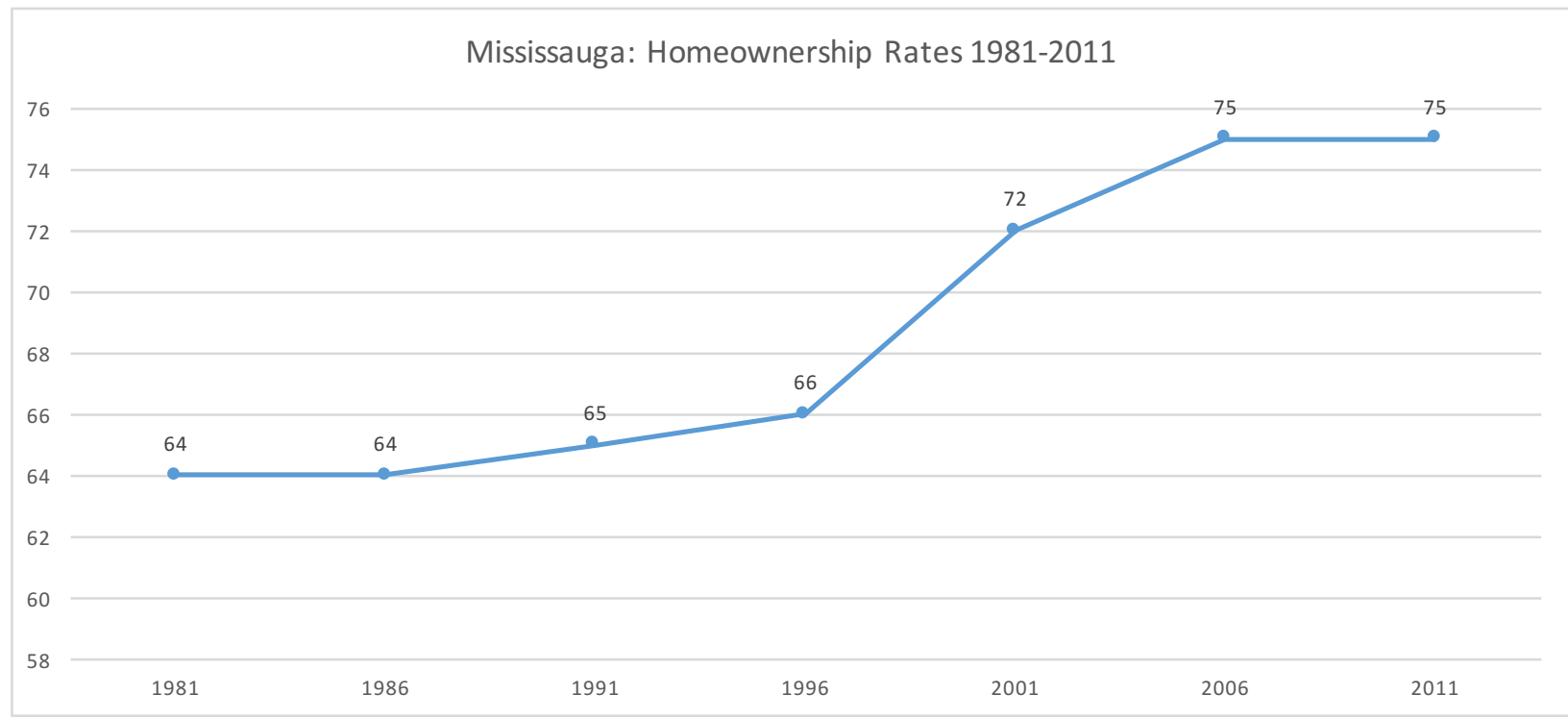

Figure 9 Homeownership Rate Mississauga

Source: Author's calculations, using available data from Statistics Canada. CHASS 1981 cumulative. Census subdivision, Mississauga.; CHASS 1986 cumulative. Census subdivision, Mississauga.; CHASS 1991 cumulative. Census subdivision, Mississauga.; CHASS 1996 cumulative. Census subdivision, Mississauga.; CHASS 2001 cumulative. Census subdivision, Mississauga.; CHASS 2006 cumulative. Census subdivision, Mississauga.; CHASS 2011 NHS. Census subdivision, Mississauga.

Homeownership in 2011, as shown in figure 9 was about 75\%, of which $65.2 \%$ reported having a mortgage or loan (City of Mississauga, 2014). This indicates that a portion of the homeownership population have already paid off their homes. The median monthly shelter costs for owners was about $\$ 1,519$ in 2011, and about $\$ 1,062$ for renters (City of Mississauga, 2014) ${ }^{4}$. Although the shelter costs for owners were slightly higher than for renters, the money that owners use to pay off their mortgages increases the households' net wealth, whereas the money used for renters' shelter costs goes into the pockets of landlords. Once obtaining ownership status, only $26.8 \%$ of owners were spending more than $30 \%$ of their income on shelter costs, compared to $42.5 \%$ of tenants.

In Mississauga in 2011, the number of children aged 18-24 living at home was 62,810 (an increase of 13.5\% from 2006) and children aged 25 + living at home was 42,545 (an increase of $22.9 \%$ since 2006) (City of Mississauga, 2012). In 2011, 44.1\% of couples had children living with them (City of Mississauga,

\footnotetext{
${ }^{3}$ Dominant types of dwelling were not available by tenure type

${ }^{4}$ These costs include all types of dwellings.
} 
2012), compared to $42.8 \%$ in 2001 (City of Mississauga, 2002). It is interesting to note the slight increase in children living at home is paired with a decline in children under 6 and 6-14 years old living in households (City of Mississauga, 2012). Between 2006 and 2011, there was a percent change of $-0.5 \%$ and $-4.5 \%$ for children under 6 and children 6-14 years old, respectively (City of Mississauga, 2012). This indicates that although the number of children living in households is increasing, it is mainly due to young adults (18+) either not leaving, or coming back to live with their parents. Delayed behaviours to move out could also be a result of the desire to own rather than rent. Children are remaining at home until this can be achieved, rather than renting until they can afford to own.

\subsection{Future Growth}

Mississauga is in a unique place in terms of its future compared to other municipalities in the Greater Toronto Area (GTA) and Greater Golden Horseshoe Area (GGHA). Most of the City's greenfield lands have been developed and the future will focus on infilling and redevelopment (City of Mississauga, 2015). This section examines the population and the shift in types of dwellings in Mississauga, as well as the role of employment in this area. The lack of available greenfields will have an affect on the future of the municipality and will guide the direction and the growth over the next 30 years. This impacts the ability of single-detached dwellings to be constructed, which could have an impact on the cost of existing single-detached homes.

Traditionally, population and employment growth has been directed by a municipality's capacities to accommodate new housing on greenfields (City of Mississauga, 2013). The majority of Mississauga's greenfield have already been built out and the future of population and employment growth will be based on intensification and redevelopment of already built up areas (City of Mississauga, 2013). High density residential developments will be centred in the city's downtown and major node character areas, while more medium-density housing will be the focus of redevelopment in neighbourhoods (City of Mississauga, 2013). Growth will also be dependent on demand, given that most greenfields are almost built out, the supply of single-detached homes will begin decreasing, and may contribute to increased demand for single-detached homes and increase unaffordability of this housing type. Based on the availability of land, and policies for intensification and redevelopment, table 1 represents the existing and future housing unit potential for the City of Mississauga (City of Mississauga, 2013). Supply of single-detached and semi-detached will decline, while row and apartment dwelling types will increase as development occurs through infill and redevelopment (City of Mississauga, 2013). The 
percentage change shows the potential increases in housing stock by type of dwelling, indicating that there is not much room for the supply of single-detached to increase, and there is a higher potential for row (townhouses) and apartment supply.

\begin{tabular}{|l|l|l|l|l|l|}
\hline \multicolumn{7}{|c|}{$\begin{array}{c}\text { Existing \& Future Housing Unit Potential } \\
\text { City of Mississauga, 2013 }\end{array}$} \\
\hline & \multicolumn{1}{|c}{ Single } & \multicolumn{1}{c|}{ Semi } & \multicolumn{1}{c|}{ Row } & \multicolumn{1}{c|}{ Apartment } & \multicolumn{1}{c|}{ Total } \\
\hline Existing & 96,100 & 31,000 & 36,600 & 75,400 & 239,100 \\
\hline Potential & 800 & 2,200 & 13,100 & 57,300 & 73,400 \\
\hline Total & 96,900 & 33,200 & 49,700 & 132,700 & 312,500 \\
\hline Percent Change & 0.8 & 7.1 & 35.7 & 76 & 30.6 \\
\hline
\end{tabular}

Table 1 Existing \& Future Housing Unit Potential

Source: Hemson Consulting Ltd., based on City of Mississauga data

According to Mississauga Real Estate Board annual sales for single-detached home for 2016 were $7.9 \%$ lower than 2015 levels, while the price ranges for single-detached homes have increased (Mississauga Real Estate Board, n.d.). Table 2 represents the change in sales by category from 2015-2016 along with the year-over-year percentage change for sales by price (Mississauga Real Estate Board, n.d.). The median number of days on the market for single-detached homes was between 1-10 for all price ranges (Mississauga Real Estate Board, n.d.). Mississauga Real Estate Board would describe the singledetached market as "an unprecedented level of demand relative to available supply" (Mississauga Real Estate Board, n.d.). Additionally, supply for single-detached homes in the lower price ranges has dried up, resulting in minimal sales activity despite continuous demand (Mississauga Real Estate Board, n.d.). Similarly, supply for price ranges below $\$ 500 \mathrm{~K}$ of semi-detached homes has also dried up, although demand remains high (Mississauga Real Estate Board, n.d.). The highest price range for semi-detached homes spent the least amount of time on the market before selling (Mississauga Real Estate Board, n.d.). Townhouses displayed strong demand in the $\$ 500 \mathrm{~K}-\$ 600 \mathrm{~K}$ range as households may be opting for purchasing townhouses over single-detached homes (Mississauga Real Estate Board, n.d.). Condominiums may be the most affordable option for homeowners. This type of swelling also shows a lack of supply where demand is high, in the $\$ 150 \mathrm{~K}$ range. 


\begin{tabular}{|c|c|c|c|c|c|}
\hline \multicolumn{6}{|c|}{ Percent Change in number of Sales by Category and by Price Range } \\
\hline \multicolumn{6}{|l|}{ Single-Detached } \\
\hline \multirow{2}{*}{$\begin{array}{c}\text { Annual percent } \\
\text { Change from } \\
2015: \\
\# \text { of Sales }\end{array}$} & \multicolumn{5}{|c|}{$\begin{array}{c}\text { Sales by Price Range } \\
\text { Year-over-year Percent Change: }\end{array}$} \\
\hline & $<\$ 400 \mathrm{~K}$ & $\$ 400 \mathrm{~K}-\$ 600 \mathrm{~K}$ & $\$ 600 \mathrm{~K}-\$ 800 \mathrm{~K}$ & $\$ 800 K-\$ 1 M$ & $>\$ 1 \mathrm{M}$ \\
\hline-7.9 & $0.0^{1}$ & -80.9 & $-49 \cdot 4$ & 67.9 & 102.3 \\
\hline \multicolumn{6}{|l|}{ Semi-Detached } \\
\hline $\begin{array}{c}\text { Annual percent } \\
\text { Change from } \\
\text { 2015: }\end{array}$ & \multicolumn{5}{|c|}{$\begin{array}{c}\text { Sales by Price Range } \\
\text { Year-over-year Percent Change: }\end{array}$} \\
\hline \# of Sales & $<\$ 400 \mathrm{~K}$ & $\$ 400 \mathrm{~K}-\$ 500 \mathrm{~K}$ & $\$ 500 \mathrm{~K}-\$ 600 \mathrm{~K}$ & $\$ 600 \mathrm{~K}-\$ 700 \mathrm{~K}$ & $>\$ 700 \mathrm{~K}$ \\
\hline+5.5 & -100.0 & -99.0 & $-55 \cdot 9$ & 98.6 & $1214 \cdot 3$ \\
\hline \multicolumn{6}{|l|}{ Condo Townhouse } \\
\hline $\begin{array}{c}\text { Annual percent } \\
\text { Change from } \\
\text { 2015: }\end{array}$ & \multicolumn{5}{|c|}{$\begin{array}{c}\text { Sales by Price Range } \\
\text { Year-over-year Percent Change: }\end{array}$} \\
\hline \# of Sales & $<\$ 300 \mathrm{~K}$ & $\$ 300 K-\$ 400 K$ & $\$ 400 \mathrm{~K}-\$ 500 \mathrm{~K}$ & $\$ 500 \mathrm{~K}-\$ 600 \mathrm{~K}$ & $>\$ 600 \mathrm{~K}$ \\
\hline+4.5 & -42.0 & -69.2 & -32.2 & 392.9 & 152.6 \\
\hline \multicolumn{6}{|l|}{ Condo Apartment } \\
\hline $\begin{array}{c}\text { Annual percent } \\
\text { Change from } \\
\text { 2015: }\end{array}$ & \multicolumn{5}{|c|}{ Sales by Price Range } \\
\hline \# of Sales & $<\$ 150 \mathrm{~K}$ & $\$ 150 \mathrm{~K}-\$ 250 \mathrm{~K}$ & $\$ 250 \mathrm{~K}-\$ 350 \mathrm{~K}$ & $\$ 350 \mathrm{~K}-\$ 450 \mathrm{~K}$ & $>\$ 450 \mathrm{~K}$ \\
\hline+16.9 & -100.0 & -60.6 & 23.0 & 148.6 & 110.7 \\
\hline
\end{tabular}

Table 2 Percent Change in number of Sales by Category and by Price Range

Source: Author's calculations, using data from Mississauga Real Estate Board, Sales by Price Range and Mississauga Real Estate Board, Sales by Category.

${ }^{1}$ No change since 2015, according to data, supply dried up in 2014 .

\subsection{Housing Affordability in Mississauga}

Section 2.3 explored the affordability issues, the need to increase affordable homeownership and the importance of it. This section looks at housing affordability issues as it relates to the City of Mississauga. Population, household type and type of dwellings available, all have an impact on housing demand (City of Mississauga, 2016). In Mississauga the overall demand of housing is expected to increase by $20 \%$ by 2036 (City of Mississauga, 2016). The population increased by $6.7 \%$ between 2006 and 2011 (City of Mississauga, 2016) and although the population only increased 1.1\% between 2011 and 2016 (Statistics Canada, 2016), it is expected to increase another 14.9\% by 2036 from 2011 (City of 
Mississauga, 2016). By 2036, the number of households is expected to reach 280,800 which is about a 19.7\% growth since 2011 (City of Mississauga, 2016). The age structure in Mississauga is also changing and the number of seniors is increasing. Older adults $\left(55^{+}\right)$accounted for only $14 \%$ of the population in 1991, however by 2011 this increased to 23\% of the total population in Mississauga (City of Mississauga, 2016). Seniors $65+$ increased by $24 \%$, reaching $11.4 \%$ of the total population in Mississauga. The aging population is indicative of a need to alter dwelling types to accommodate for the changing demographics and provide housing that is suitable for all populations (City of Mississauga, 2016).

The types of dwellings that should be built in Mississauga is tricky, there is a growing need for smaller units to accommodate households made of of one- and two-persons but there is also a growing need for larger units as four- and five-person households are also increasing (City of Mississauga, 2016). The number of larger households in Mississauga is unlike many Ontario communities, in 2011 four-person households made up $21.7 \%$ of the population, while 5 or more-person households made up $15.7 \%$ (City of Mississauga, 2016). Additionally, Mississauga's population in becoming increasingly diverse. In 2011, 1 in every 12 Mississauga residents is a recent immigrant, immigrant households made up $63.8 \%$ of all households in Mississauga, and 75.8\% of these were homeowners (City of Mississauga, 2016). In 2011, $10.8 \%$ of households have a member with a disability (City of Mississauga, 2016). The diversity of the population in terms of age, background, and structure all indicate a need to have a wide range of housing types for all residents including housing that is accessible (City of Mississauga, 2016).

The income gap in Mississauga has increased, further polarizing the poorest and the richest households in the city. In 2010 , the average household income was $\$ 95,052$, up $7.4 \%$ from 2005 , which was $\$ 88,512$ (City of Mississauga, 2016). The lowest $10 \%$ of households and the highest $10 \%$ share an astonishing gap, earning an average of $\$ 21,589$ and $\$ 177,369$, respectively (City of Mississauga, 2016). Housing affordability issues refer to households that spend $30 \%$ or more of their income on housing costs, deep housing affordability issues refer to households spending 50\% or more of their income on housing costs and finally severe affordability issues refer to households spending $70 \%$ or more of their income on housing costs (City of Mississauga, 2016). Figure 10 indicates the proportion of households that fall under each of the housing affordability issues in Mississauga in 2011. It is evident that there are significant housing affordability issues in Mississauga (City of Mississauga, 2016). Both renters and owners experience these issues, however, a significantly larger portion of renters face affordability issues than owners. $26.8 \%$ of all owner households were spending $30 \%$ or more of their income in 2011 , 
while $11.4 \%$ were spending $50 \%$ or more (City of Mississauga, 2016). $42.5 \%$ of all renters experienced housing affordability issues spending $30 \%$ or more, while $20.4 \%$ of renters were spending $50 \%$ or more (City of Mississauga, 2016). As mentioned in section 3.2 Tenure, the average cost of living between owners and renters is not dramatically different, however the benefits that ownership households gain may outweigh the additional costs of owning. For instance, the money that is being spent on shelter is a direct investment into the household, rather than renting where the money is not going back to the household.
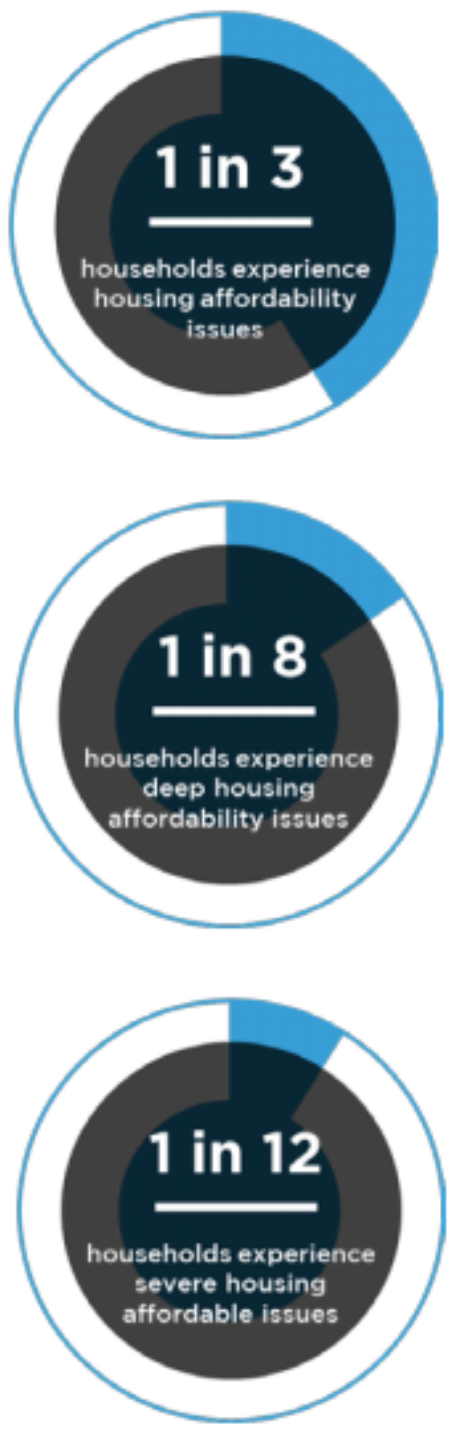

Figure 10 Mississauga Housing Affordability Issues (2011) Source: City of Mississauga. Affordable Housing Program - Housing Gap Assessment 
This City of Mississauga's Affordable Housing Program - Housing Gap Assessment (2016) indicates that certain household types may be more susceptible to housing affordability issues. Figures 11 and 12 indicate the percentage of households that have housing affordability issues and deep housing affordability issues based on household type ${ }^{5}$. Additionally, the majority of households in core housing need fell below the affordability standard (City of Mississauga, 2016). 91.6\% of households in core need lived in homes that were not affordable (City of Mississauga, 2016). 15.3\% of all households in 2011 were in core housing need. This data is a clear indication that there is an affordability issue in Mississauga that needs to be addressed. Creating dwelling types suitable for the changing population is an essential part in ensuring housing is suitable for each household type as well as ensuring they are affordable for households to have housing stability.

\section{Housing Affordability Issues by Household Type}

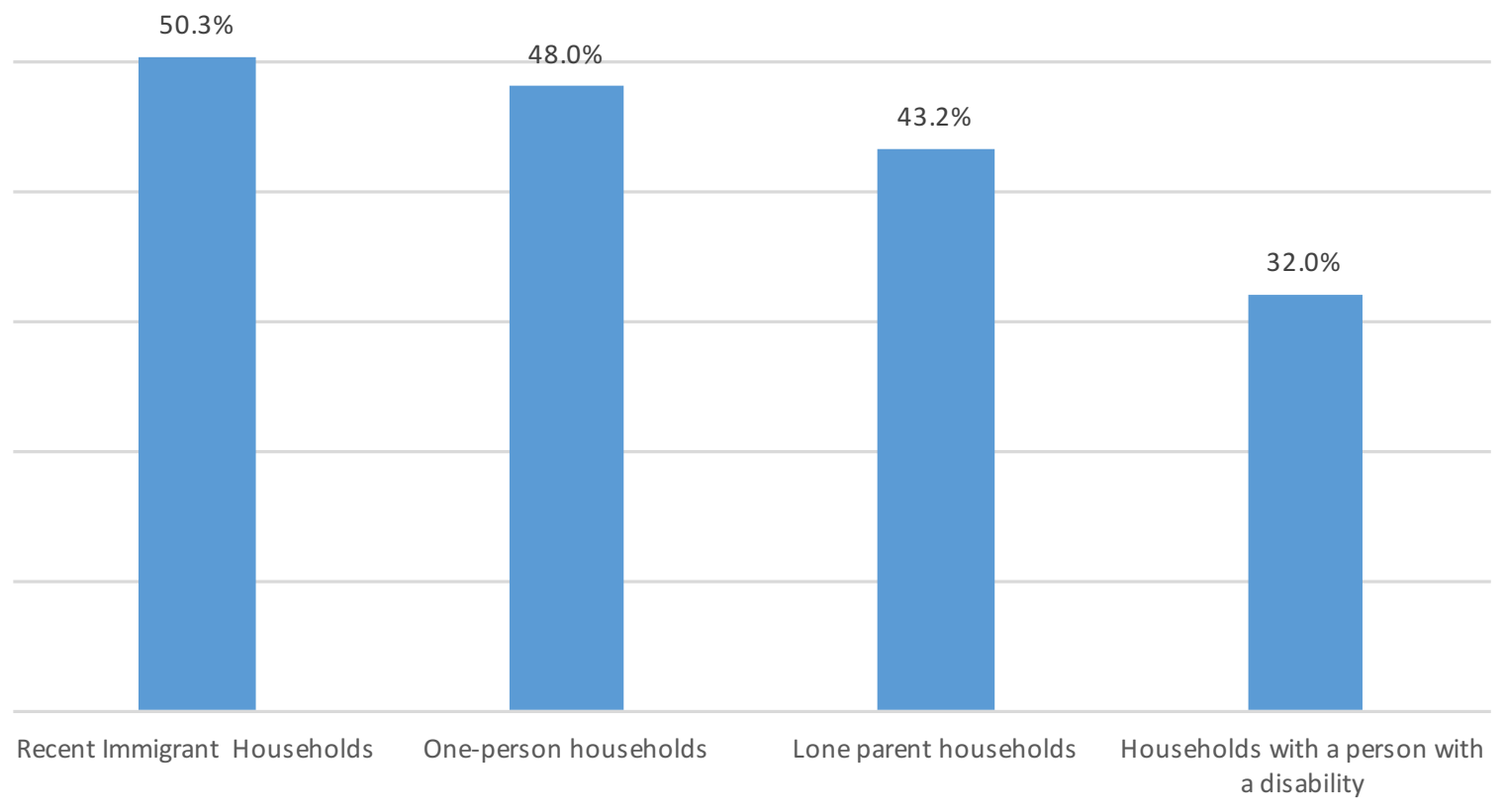

Figure 11 Mississauga Housing Affordability Issues by Household Type (2011) Source: City of Mississauga. Affordable Housing Program - Housing Gap Assessment.

\footnotetext{
${ }^{5}$ Data was not available to categorize housing affordability issues by tenure.
} 


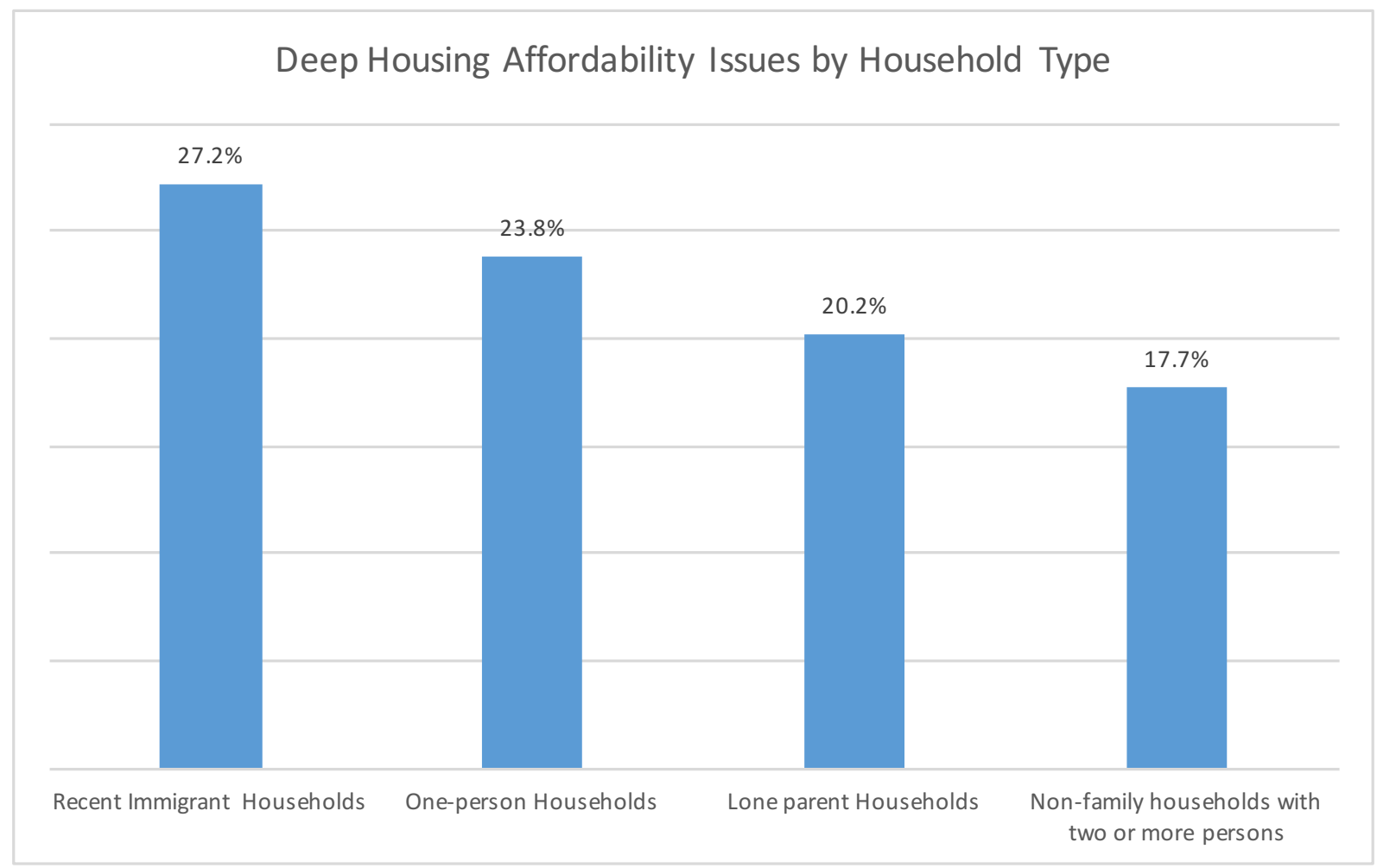

Figure 12 Mississauga Deep Housing Affordability Issues by Household Type (2011)

Source: City of Mississauga. Affordable Housing Program - Housing Gap Assessment.

Households in Mississauga now, are living in more high-density structures than they were in the past.

While the most dominant type of dwelling is still single-detached dwellings, apartment units are slowly increasing to catch up with the single-detached supply (City of Mississauga, 2016) ${ }^{6}$. Additionally, the number of single-detached starts will decline due to lack of available space, but apartment starts will continue to increase. Figure 13 represents the distribution of the supply of dwellings by type in Mississauga in $2011^{7}$. The average price of houses in Mississauga has increased, from $\$ 421,096$ to $\$ 546,720$ between 2011 and 2015 (City of Mississauga, 2016) ${ }^{8}$. In Mississauga, "the demand for affordable ownership dwellings does not match the supply" (City of Mississauga, 2016). 52.3\% of all owners have incomes ranging from $\$ 25,458$ to $\$ 99,875$ (Decile 1 to 6 ), while only $27.8 \%$ of the ownership housing is actually affordable to these households. Figure 14 and 15 show the affordability of ownership housing and rental housing in Mississauga. As house prices have increased, ownership is becoming increasingly unattainable for low and moderate income earners (City of Mississauga, 2016).

\footnotetext{
${ }^{6}$ Dominant type of dwelling not available by tenure type.

${ }^{7}$ For all tenure types.

${ }^{8}$ For all housing types
} 
Although this paper is primarily focused on ownership affordability, it is important to note that market rents are still unaffordable to about $30 \%$ of renters (City of Mississauga, 2016).

\section{Supply of Dwellings by Type}

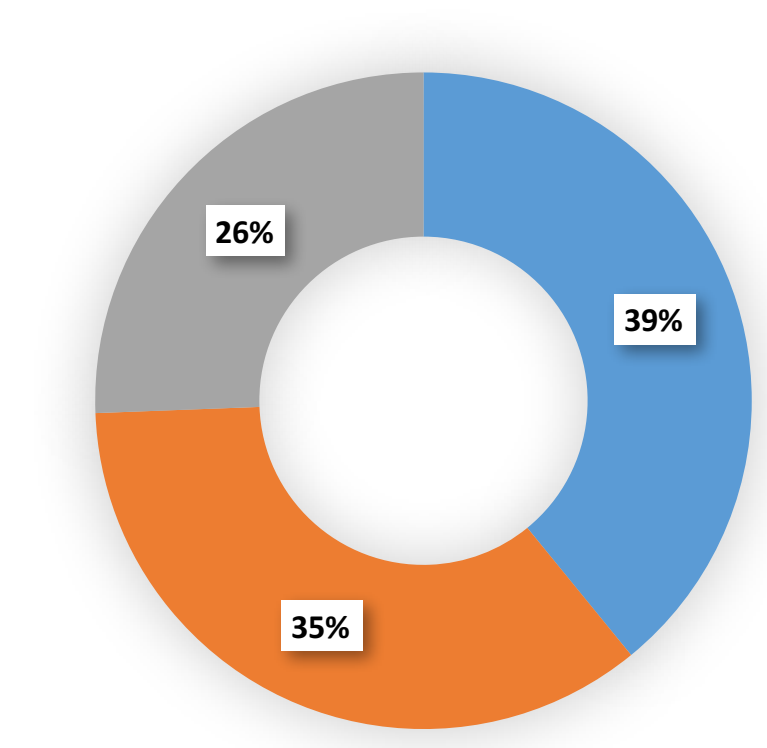

- Single-detached dwellings

Apartment units

Semi-detached and row houses

Figure 13 Mississauga Supply of Dwellings by Type (2011)

Source: City of Mississauga. Affordable Housing Program - Housing Gap Assessment. 
Ownership Housing Affordability

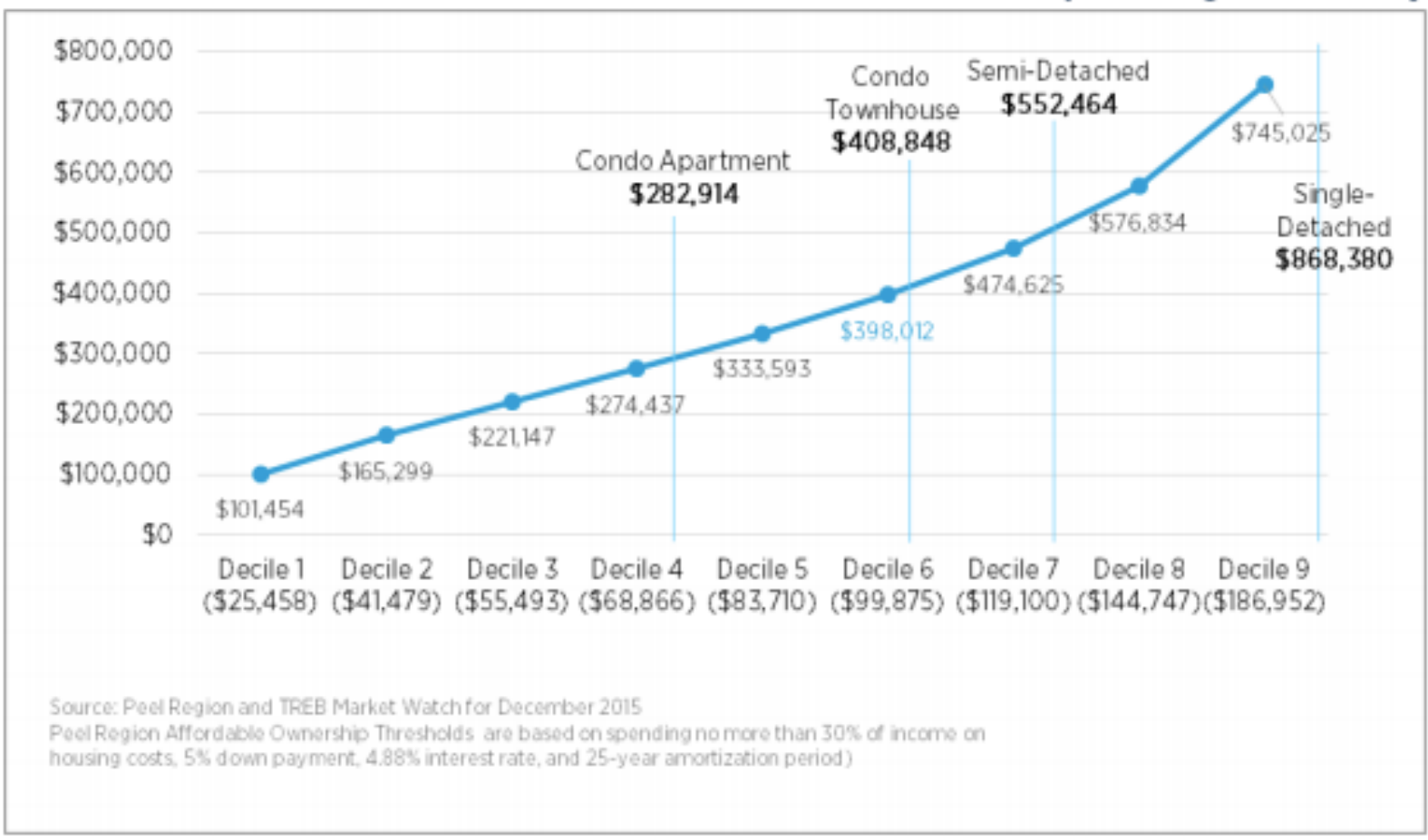

Figure 14 Mississauga Ownership Housing Affordability Source: City of Mississauga. Affordable Housing Program - Housing Gap Assessment.

More than $40 \%$ of Mississauga ownership households are unable to afford owning a home unless they spent $30 \%$ or more of their income on housing costs or make a down payment greater than $5 \%$ of the purchase price (City of Mississauga, 2016). The idea of owning a single-detached home will remain an idea or a dream for the majority of residents in Mississauga. Even ownership households in Decile 9 would have to spend $30 \%$ or more of their income in order to affordably own an averagely priced singledetached home. 
Rental Housing Affordability

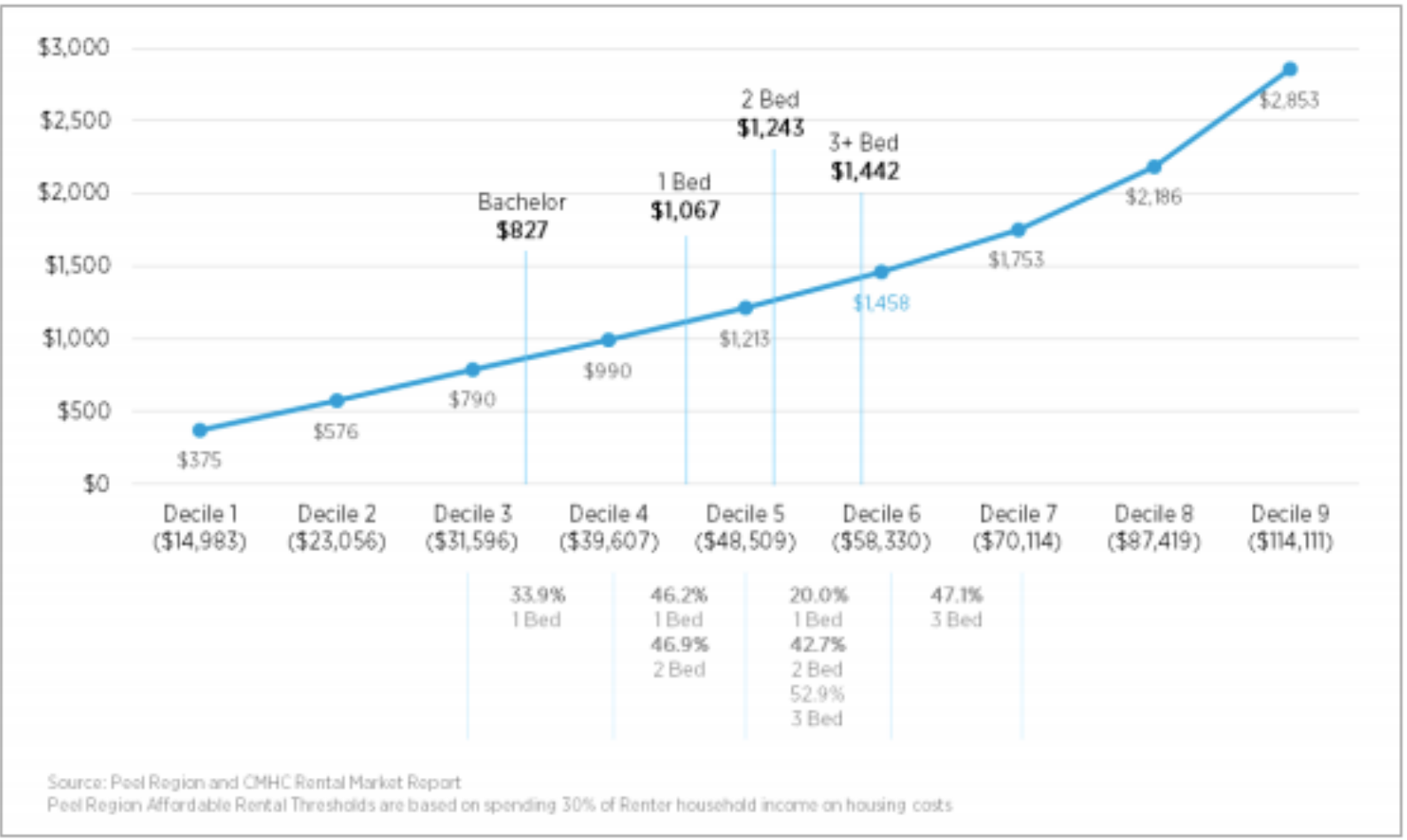

Figure 15 Mississauga Rental Housing Affordability

Source: City of Mississauga. Affordable Housing Program - Housing Gap Assessment.

The rental affordability, figure 15 , indicates that rental households in the $4^{\text {th }}$ Decile would not be able to afford rent for a one-bedroom unit, and households in the $5^{\text {th }}$ Decile would not be able to afford $3^{+}$ bedrooms without spending $30 \%$ or more of their income (City of Mississauga, 2016).

Figure 16, represents the affordability thresholds for both rental and ownership in Mississauga, based on income Deciles created by the Region of Peel and applied to households in the City of Mississauga (City of Mississauga, 2016). Affordability was defined by households spending 30\% of their income on shelter costs (City of Mississauga, 2016). These figures indicate the house types that are affordable options to households in Mississauga based on income. Households that are considered low income are in Deciles 1-3 with incomes up to $\$ 55,493$, moderate income households are between the $4^{\text {th }}$ and $6^{\text {th }}$ Deciles with incomes between $\$ 55,494$ and $\$ 99,875$ and high income households are in Decile 7 to 10 and have incomes over $\$ 99,875$ (City of Mississauga, 2016). It is evident that there are limited options for low income households in Mississauga, this category is comprised of $31.8 \%$ of all households in the city, $54 \%$ of low income households are owners, while $46 \%$ are renters (City of Mississauga, 2016). $69.2 \%$ of all households in this category have housing affordability issues, $40.2 \%$ have deep housing affordability issues and $25.3 \%$ have severe housing affordability issues (City of Mississauga, 2016). The 
most vulnerable household types within the low income households category include couples with children, multiple family households, recent immigrant households, lone parents, and non-family households with two or more people (City of Mississauga, 2016). Moderate income households have a slightly larger range of options for affordable housing, but $26.1 \%$ are still experiencing affordability issues (City of Mississauga, 2016). This category is comprised of $28.8 \%$ of all Mississauga households, $2.6 \%$ of these households are spending more than $50 \%$ and have deep housing affordability issues and only $0.4 \%$ of these households have severe housing affordability issues (City of Mississauga, 2016). The most vulnerable household types in this category include couples with children and multiple family households (City of Mississauga, 2016). Finally, the last category are the high income households, which have the largest range of housing choices (City of Mississauga, 2016). 39.4\% of all households in Mississauga fall within the $7^{\text {th }}$ and $10^{\text {th }}$ Deciles. Only $2.6 \%$ of these households spend more than $30 \%$ of their income, and 145 households are spending more than 50\%, however it should be noted that households in this income range may be choosing to spend this much on housing as there are more affordable options available to them (City of Mississauga, 2016). Figure 16 shows that there are more households between Decile 1 and 6 than there are available ownership units, which increase the chances of unaffordability among these income groups. Demand exceeds supply, $31.8 \%$ to $17.9 \%$ between Decile 1 and 3, and $28.8 \%$ to $27.2 \%$ between Decile 4 and 6 (City of Mississauga, 2016). On the contrary, supply exceeds demand between Deciles 7 and 10, with $54.9 \%$ supply and $39.4 \%$ demand (City of Mississauga, 2016). 


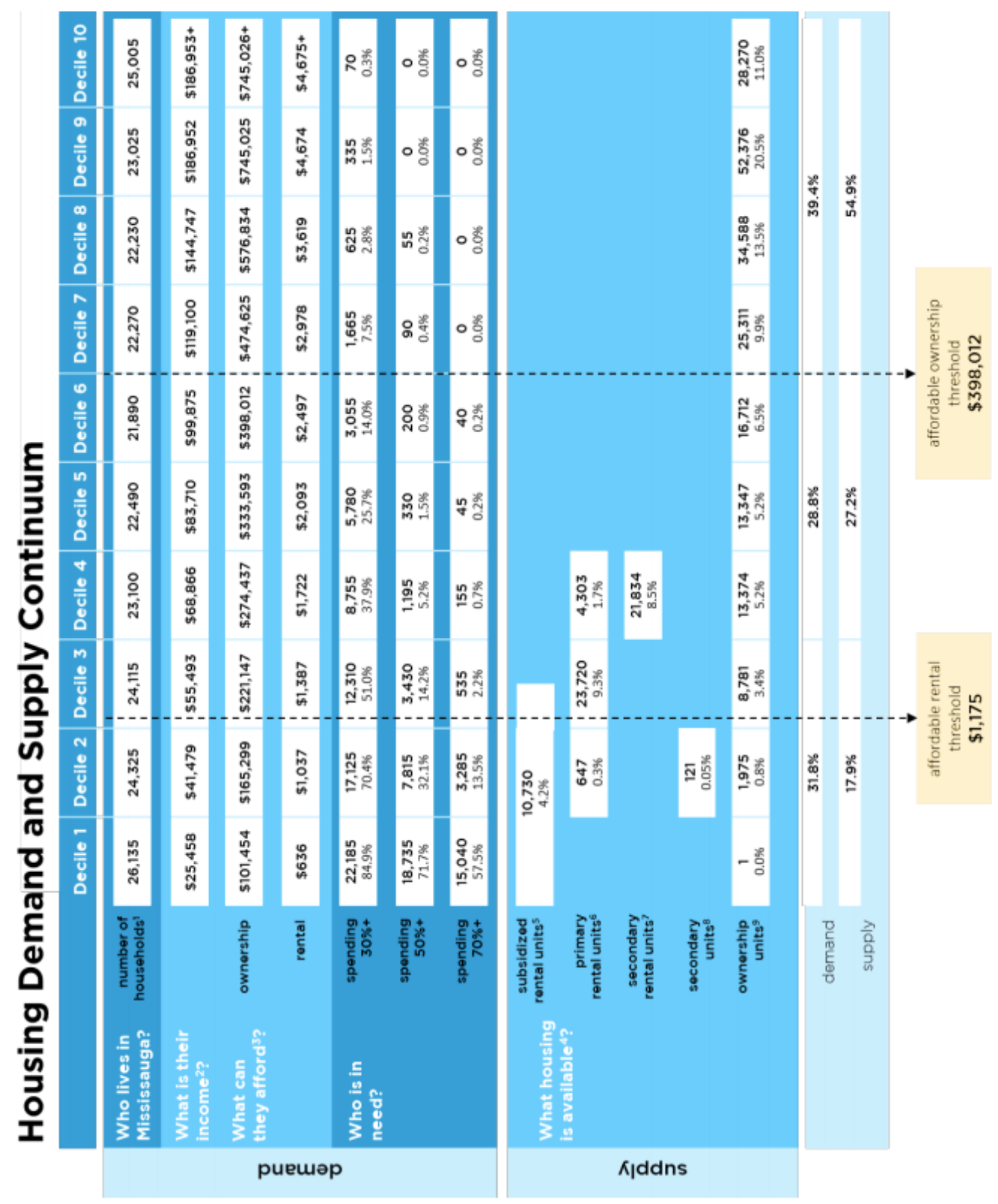

Figure 16 Mississauga Housing Demand and Supply Continuum Source: City of Mississauga. Affordable Housing Program - Housing Gap Assessment. 


\section{POLICIES AND PLANS}

This section identifies provincial, regional and municipal policies that would have an effect on development and growth and has potential to affect the housing affordability in Mississauga. It examines policies and documents that have direct and indirect consequences on housing affordability in Mississauga. Provincial policies guide local planning decisions and municipal policies must comply with and sometimes conform to provincial policies.

\subsection{Provincial}

\subsubsection{Planning Act, 1990}

The planning act is a piece of legislation intended to guide development and growth within the province of Ontario. It outlines that municipal governments have authority over certain planning decisions as long as they conform to the guidelines outlined in the Planning Act. Each planning decision must also have the provincial interest in mind. The Planning Act outlines how municipalities can administer their own guidelines and policies of growth and development based on local needs and wants (Province of Ontario, 2016).

The Planning Act is important to shaping the future of affordable housing, particularly affordable homeownership. The purpose of this Act is to guide the other provincial, regional and municipal policies that have an impact on the shape and structure of future growth. The Planning Act guides regional and municipal official plans that play a role in how the supply of all types of housing tenure is distributed within these areas.

\subsubsection{Provincial Policy Statement, 2014}

The Provincial Policy Statement (PPS) is under section 3 of the Planning Act, in which the Minister alone or with any other minister of the Crown may pass a policy statement relating to municipal planning matters that are of provincial interest (Province of Ontario, 2014). The Provincial Policy Statement has three overarching policies which include, building strong healthy communities, wise use and management of resources and protecting public health and safety (Province of Ontario, 2014). 
Section 1.4 of the PPS addresses housing. It states that municipalities must provide an appropriate range and mix of housing types and densities to accommodate for current and future residents. Planning authorities must ensure that they establish and implement minimum targets for the provision of housing which is affordable to low and moderate income households. (Province of Ontario, 2014)

In order to ensure that there is an available range of housing, municipalities need to be aware of the affordable homeownership issues and use the PPS to help guide their local policies. These local policies can directly impact on the availability of affordable housing, particularly homeownership.

\subsubsection{Proposed Growth Plan for the Greater Golden Horseshoe, 2016}

In 2016, the Province released a Proposed Growth Plan for the Greater Golden Horseshoe that better reflects intensification and growth targets for municipalities in the GGHA than the 2006 version. This section focuses on the targets set out by the Proposed Growth Plan. The Growth Plan for the Greater Golden Horseshoe, 2006 (Growth Plan) was the first document that provided a framework for implementing the province's idea for building stronger, prosperous communities by improving the management of growth for the region. In addition to that, it provides guidance for improving the ways our cities, towns and suburbs grow over time.

The Growth Plan is intended to direct and guide the growth and future development of municipalities within the Greater Golden Horseshoe in order to accomplish their visions. Some aspects of this vision include sustainable infrastructure, residents have easy access to shelter, food, education and healthcare facilities, public services are located in community hubs, there is an integrated transportation network to allow residents to get around easily, and public transportation be affordable and efficient (Ministry of Municipal Affairs and Housing, 2016). The GGHA should resemble a healthy natural environment with clean air, land and water, it should allow for residents to access natural environments, while protecting the environmentally sensitive areas that surround the region (Ministry of Municipal Affairs and Housing, 2016).

Growth will be focused on Urban Growth Centres and transit corridors and station areas, which will be defined in Official Plans. The section 2.2.6 Housing (Appendix B: Policy) identifies the need for municipalities to have a housing strategy to mitigate issues that are present within their jurisdiction and to ensure that all residents have equal access to shelter (Ministry of Municipal Affairs and Housing, 
2016). It is particularly important that municipalities recognize the housing issues related to affordable homeownership. Homeownership plays a significant role in local economies and adding societal benefits. By focusing on these issues, municipalities will be able to adhere to The Growth Plan's vision.

\subsubsection{Inclusionary Zoning}

Inclusionary Zoning is a concept that has been adopted in many municipalities in England and the United States. It would allow municipal authorities to require affordable units as part of residential developments. Bill 7, the Promoting Affordable Housing Act, 2016 was given Royal Assent on December 8,2016 . This means that the Bill was passed and gives municipalities the option of requiring inclusionary zoning.

Implementing inclusionary zoning would help to achieve the following:

- Serving more people: it would increase the supply of affordable housing that serves the needs of low-to moderate income households

- It would help to create inclusive and integrate communities

- It would meet local needs: it can help municipalities meet their housing targets and goals in their homelessness plans and official plans

(Ministry of Municipal Affairs and Housing, 2017).

The passing and adoption of Bill 7, Promoting Affordable Housing Act, 2016 will impact the following policies and plans:

- Development Charges Act, 1997

- Elderly Persons Housing Aid Act

- Housing Services Act, 2011

- Planning Act

- $\quad$ Residential Tenancies Act, 2006

- Smart Growth for our Communities Act, 2015

Inclusionary zoning is an important aspect when tackling affordable homeownership. It allows municipalities to have the power to require affordable units in new builds. It also encourages a mix of demographics rather than a complete segregation of rich and poor based on dwelling type. It creates diversity within buildings and neighbourhoods. 


\subsection{Regional}

\subsubsection{Region of Peel Official Plan}

The purpose of this plan is to provide an overarching framework for development and growth in the Region of Peel; integrating environmental, social, economic and cultural imperatives as well as encouraging sustainable development (Region of Peel, 2016). This regional plan overlooks the municipalities in Peel, which include Caledon, Brampton and Mississauga.

The Region of Peel Official Plan addresses provisions of housing to meet needs in order to provide a higher quality of life for Peel residents. The general objectives of the housing section of this plan are to provide an appropriate mix and range of housing types, to foster availability of housing for all income groups, to foster efficient and environmentally sensitive use of land, and to achieve annual minimum new housing unit targets, including affordable housing (Region of Peel, 2016). The policies that adhere to these objectives can be found in Appendix B: Policy.

Section 5.8.3 of the official plan addresses Supply of Affordable Housing, which indicates a need to increase the supply of affordable rental and affordable ownership housing within the region. The policies that address this objective can be found in Appendix B: Policy. Other sections of housing in the Region's Official Plan include retention of existing rental housing stock, energy efficient housing, housing options for persons with special needs and diverse populations, and addressing the barriers to access housing (Region of Peel, 2016).

\subsection{Municipal}

\subsubsection{City of Mississauga Official Plan}

The City of Mississauga Official Plan provides a framework to protect, enhance, restore and expand the Natural Heritage System, to direct growth to enhance the existing urban form, support a strong public transportation system and address issues pertaining to long term sustainability of the city (City of Mississauga, 2015). The plan discusses directing growth and that housing and job growth will be balanced and phased to ensure that services and amenities remain on pace with development (City of Mississauga, 2015). The Plan ensures that it adheres to and is consistent with other policies, such as the PPS, The Growth Plan and Region of Peel Official Plan. 
Mississauga is made up of various land uses and designated specific character areas. Major Nodes provide the city with higher density housing through different phases for a variety of income groups (City of Mississauga, 2015). Community Nodes provide residents with access to everything needed for daily living; these areas are expected to have a diverse housing stock that meet the housing needs of the populations adjacent to these nodes (City of Mississauga, 2015). Some of the City's neighbourhoods are historic, but the majority of them were built in the late $20^{\text {th }}$ Century and the housing stock in these areas are relatively new and in a good state of repair (City of Mississauga, 2015).

The Official Plan guides where and what type of housing are being permitted in certain character areas. Neighbourhoods are only be permitted to accommodate for low and mid-density dwellings, not exceeding 4 storeys (City of Mississauga, 2015). The Official Plan's Complete Communities section has policies regarding meeting the needs of people of all ages, abilities and income groups. As well as having provision to ensure suitable housing so that youth, older adults and immigrant can thrive within these communities (City of Mississauga, 2015). Section 7.2 describes the policies under the Official Plan Complete Communities that pertain specifically to housing and under section 7.2.2, the City plans to provide opportunities for developing a range of housing types, variety of affordable dwelling types, both rental and ownership and producing houses for those with special needs, such as the elderly (Appendix B: Policy) (City of Mississauga, 2015). 


\section{EXISTING PROGRAMS}

This section outlines programs that currently exist to help alleviate the housing affordability issue. These programs target both rental and ownership affordability.

\subsection{Federal/Provincial}

\subsubsection{Canada Mortgage and Housing Corporation - Affordable Housing Programs} in Ontario

The Canada Mortgage and Housing Corporation has many programs to help Ontario residents achieve affordable housing (Canada Mortgage and Housing Coporation, 2017). Programs aim to increase the supply of affordable housing, to improve housing affordability, to renovate and repair housing and to foster safe independent living (Canada Mortgage and Housing Coporation, 2017). These programs target both renters and homeownership, as well as population groups that are more vulnerable to unaffordable housing.

Two programs in particular pertain specifically to affordable homeownership. The first program is called Ontario Renovates, some of the objectives of this program are to improve living conditions through financial assistance, to foster independent living for seniors and persons with disabilities through home improvements to be more accessible and accommodating, and to increase supply of affordable rentals by assisting to create secondary suites (Canada Mortgage and Housing Corporation, 2014). CMHC provides forgivable loans to ensure that homes remain suitable for households. This program targets homeowners as well as landlords to improve rental units. There are restrictions that apply for the loan to be forgivable and other conditions associated with funding. For home repairs $75 \%$ of the estimated project costs are given within 15 business days of the project approval, the remaining $25 \%$ is awarded once repairs are complete and projects costs are finalized (Canada Mortgage and Housing Corporation, 2014). For landlords or renovations in multi-unit buildings, $50 \%$ of funding is awarded when the funding agreement is signed, another $40 \%$ granted when $50 \%$ of the work is completed and the remaining $10 \%$ is granted after the completion of renovations and submission of post-repair occupancy report (Canada Mortgage and Housing Corporation, 2014). This program has a maximum funding capacity of $\$ 50,000 /$ nit and service manager's area cannot exceed an average of $\$ 25,000 /$ unit (Canada Mortgage and Housing Corporation, 2014). 
The second program is called the Home Ownership Program, the objective of this program is to assist with down payments when purchasing a home (Canada Mortgage and Housing Corporation, 2014). It is a forgivable loan and provides renters an opportunity to move into homeownership (Canada Mortgage and Housing Corporation, 2014). It also eases rental demand and encourages developers to build affordable housing by fostering ownership demand (Canada Mortgage and Housing Corporation, 2014). This program is targeted towards both owners and renters looking to purchase a primary residence and are below the $60^{\text {th }}$ percentile income level for the area they are purchasing in (Canada Mortgage and Housing Corporation, 2014). Similar to Ontario Renovates, this program also provides a forgivable loan (Canada Mortgage and Housing Corporation, 2014). However, this loan is only forgivable after a 20year period and abiding to all associated conditions. This program has a maximum funding capacity of $\$ 50,000 /$ unit and total funding must not exceed $10 \%$ of the purchase price (Canada Mortgage and Housing Corporation, 2014). In addition to providing down payment assistance, this program also provides education for potential homeowners to learn about the up-front and on-going costs of being a homeowner (Canada Mortgage and Housing Corporation, 2014).

These programs are funded by the Investment in Affordable Housing for Ontario Program (IAH), which provides and will continue providing over $\$ 800$ million in federal and provincial funding to improve access to housing between 2014 and 2020 (Canada Mortgage and Housing Corporation, 2014). Households that face deep and severe housing affordability and households that want to move into ownership can take advantage of some of the programs that help with the burden of affording a home. These two programs in particular, provide a starting point for many renters and owners to remain in suitable housing conditions and/or move into homeownership affordably.

\subsubsection{Ontario's Long-Term Affordable Housing Strategy Update}

The Province released a Long-Term Affordable Housing Strategy in 2010, and building on the 2016 Ontario Budget the updated version of the Plan was released in March 2016. The Province is committed to new operating and capital funding to support this plans initiatives (Province of Ontario, 2016). This plan sets out to guide Ontario municipalities in tackling homelessness and affordable housing issues.

The updated version of the plan included some key themes that arose during the consultation process. The updated version addresses these common themes:

- Supply of affordable housing need to be increased (both for rental and ownership) 
- $\quad$ Rent-Geared-to-Income system needs to be revamped

- Housing assistance should be portable

- Access to housing and services should be simpler so that families and individuals have easier access to these services

- $\quad$ Access to support services needs to be expanded and made easier for tenants receiving housing assistance

- Ontario need an Indigenous Housing Strategy

- Service Managers and housing providers need better data to optimize decision making (Province of Ontario, 2016).

This plan is intended to guide local initiatives and plans in providing housing that is accessible to all residents of Ontario. The overarching vision for this plan is to support social and economic inclusion, end chronic homelessness and meet all housing need for all Ontarians. The two main objectives outlined in this plan are to decrease the number of people who are homeless and increase the number of families and individuals achieving housing stability. This plan targets owners, renters and the homeless and is provincially funded. The funding for this program is increasing, growing from $\$ 2.5$ million in $2016 / 17$ to $\$ 10$ million in $2018 / 19$ (Province of Ontario, 2016). Additionally, the changes to the Building Code allows wood-frame structures to be built up to 6 storeys now, rather than 4 (Province of Ontario, 2016). This reduces construction costs of building mid-rise developments and could make housing more affordable (Province of Ontario, 2016).

Since Ontario's Long-Term Affordable Housing Strategy launched in 2010, there have been a number of successes that have contributed to affordable homeownership, both directly and indirectly. In 2012, Services Managers created housing strategies to tackle both homelessness and affordable housing, including both rental and ownership (Province of Ontario, 2016). In 2014, the Minister's forum on affordable housing and the private sector addressed the need to work with the private sector to facilitate the construction of both affordable homeownership and rental housing (Province of Ontario, 2016). After the PanAm Games in 2015 , it was announced that the Athlete's Village would convert into numerous affordable ownership units and affordable rental units (Province of Ontario, 2016). Since 2011, Investment in Affordable Housing for Ontario (IAH) has assisted almost 15,000 households (Province of Ontario, 2016). 
This Plan is a guiding framework for Mississauga when planning for the future. The City's own housing strategy will be able to take advantage of all of the initiatives offered by the Plan. The objectives identified in this plan are similar to the priorities for Mississauga, due to its size and growing unaffordability, this plan plays a key role in shaping affordability strategies. Specifically, in areas where policy only permits mid-rise developments, wood framed structures will reduce costs to allow for more cost effective and hopefully affordable units.

\subsection{Regional}

\subsubsection{Peel's Housing and Homelessness Plan 2014-2024}

As required by the Province of Ontario's Long-Term Affordable Housing Strategy, The Region of Peel developed a local homelessness and housing plan (Region of Peel, 2014). This plan is centred around putting people first and ensuring stable housing solutions to improve the quality of life and achieve social and economic outcomes for all families and individuals (Region of Peel, 2014).

This Plan has three main objectives including, ensuring available and accessible quality housing that meets people's needs and preferences throughout their lives, building individual and family capacity, and creating an environment that helps people secure and maintain housing at every stage of life and finally, implementing an integrated system that supports people's housing needs efficiently and effectively (Region of Peel, 2014).

Although this Plan focuses on eradicating homelessness, it also provides actions and strategies to improve housing standards and ensure housing stability for all residents (Region of Peel, 2014). The Plan has strategic actions to increase the supply of housing options, encourage innovative and costeffective housing solutions and other strategies to improve housing conditions. It is an important framework to guide the future of housing within the Region. Mississauga is the largest municipality in Peel Region and this Plan will greatly affect the future outlook of affordable housing, particularly affordable ownership within the City.

\subsection{Municipal}

\subsubsection{Mississauga's Affordable Housing Program}


The City of Mississauga is currently procuring an Affordable Housing Program that intends to improve access to affordable housing (City of Mississauga, n.d.). It will focus on both affordable rental and ownership and respond to the City's affordable housing needs. The program will work in partnership with all levels of government, as well as the private and not-profit sectors to increase affordable housing options for all residents.

As indicated in section 3.4 Housing Affordability in Mississauga, there needs to be a wider range of affordable options for particular types of households as well as for low and moderate income households. The City conducted a study in October 2016 on understanding the cost incentives to increase affordable options (City of Mississauga, 2016). The study focused on identifying financial drivers for increasing rental stock, financial incentives for new affordable housing, effectiveness of financial incentive tools in supporting the creation of both rental and ownership affordable housing, analysis of creating new and improving existing secondary units for homeowners, and outline considerations in the development of financial incentive strategy (City of Mississauga, 2016). Additionally, in order to drive the success of the Affordable Housing Program, Mississauga has commented on the National Housing Survey (NHS) and has requested the support of all levels of government in helping the City face their affordable housing issues (City of Mississauga, 2016). The report suggests that the continuous funding of existing social housing, and creating new programs for new affordable ownership and purpose-built rental are a few things that the City needs in order to successfully implement and develop an Affordable Housing Program (City of Mississauga, 2016).

Mississauga also has a huge focus on secondary units as an affordable option for households. Not only does it alleviate affordability pressures of owners but could provide affordable options for renters. The Second Units Registration By-law replaced the Second Unit Licensing By-law as of June 2016 (City of Mississauga, n.d.). "A second unit is a self-contained living unit within a detached, semi-detached house or townhouse" (City of Mississauga, n.d.). Second units must comply with the Ontario Building Code, Ontario Fire Code and the Mississauga Zoning By-law; owners are required to submit an application to the City to legalize units (City of Mississauga, n.d.). Low costs of registering and licensing secondary units create incentive for households to legalize their units and provide the opportunity to offer an additional housing option for households (City of Mississauga, n.d.). This program has identified the need to increase affordable housing within Mississauga and is moving toward developing a program that can address these issues. 


\subsection{Not-for-Profit}

\subsubsection{Habitat for Humanity Halton-Mississauga}

Habitat for Humanity Halton-Mississauga is a non-profit organization that provides affordable housing and promotes homeownership (Habitat for Humanity GTA, 2014). It embodies 5 core values; housing for all, diversity and inclusiveness, partnership, faith in action and human dignity (Habitat for Humanity Halton-Mississauga, n.d.).The organization was founded on Christian principles and they build affordable homes in partnership with low-income families. The target group for this organization is toward potential homeowners and is funded through donations, grants and revenue from the ReStores. Habitat ReStore is a retail store concept that accepts donated items including overstock, discontinued items, appliances, etc. and sells them to the public at a reduced cost, usually around $30-70 \%$ less than the original retail value (Habitat for Humanity, n.d.).

Habitat for Humanity Halton-Mississauga was created in 1999 and has "continuously offered no interest, no profit home mortgages (capped at $30 \%$ of the home income) to hard-working families in need and who agree to contribute 500 volunteer hours of "sweat equity" as the down payment of their Habitat home" (Habitat for Humanity Halton-Mississauga, n.d.). Although, Habitat for Humanity Halton-Mississauga would be a great choice to help some low income households in Mississauga, they contribute very little to housing supply. On average, Habitat for Humanity has built one home per year, but have recently set a goal to build 75 homes by 2019 (Habitat for Humanity Halton-Mississauga, n.d.).

\subsubsection{Options for Homes}

Options for Homes (Options) is a non-profit developer of condominiums, with a mission to help individuals achieve homeownership (Options for Homes, 2016). They have a model called 'Pay It Forward' that has helped over 3,500 individuals; it involves passing along cost-savings and offering down payment support (Options for Homes, 2016). Established in 1994, Options and their affiliated organizations have provided over 6,500 households with homeownership opportunities (Options for Homes, 2016). They ensure that they are building quality homes and use Deltera, a member of the Tridel group as their builder in the Greater Toronto Area (Options for Homes, 2016). Options core values are embedded in "community, collaboration, selflessness, working together towards a common goal for the common good" (Options for Homes, 2016). 
The Options Contribution is a program that helps with down payments (Options for Homes, 2016). The loan boosts your down payment to about 10-13\% of the purchase price of your suite (Options for Homes, 2016). There is no payment due until you sell or rent your suite, and the loan appreciates by the same percentage as the resale value and must be paid back in full (Options for Homes, 2016). The loans that are repaid go back into the reserve that funds The Options Contribution (Options for Homes, 2016). Anyone who is purchasing a home with Options may take advantage of this opportunity (Options for Homes, 2016).

Options for Homes is a great choice for first-time home buyers, young families or seniors that wish to live in condominiums. The down payment program helps to alleviate the barriers associated with entering homeownership. They only provide one dwelling type so it does not cater to all household types but is still a suitable choice for many.

\subsubsection{Analysis of Existing Programs}

The programs and organizations have provided a good understanding of the existing options for providing affordable housing as well as alleviating affordable housing issues. Common themes the emerged through the analysis of these programs include, providing down payment assistance, increasing housing stability and the need for financial assistance from all levels of government. Providing down payment assistance is an important aspect of increasing access to affordable homeownership. As housing prices increase the amount required to purchase a home also increases; housing prices are increasing at a much faster pace than incomes. Additionally, down payments are one of the largest barriers when thinking about buying a home (Painter \& Redfearn, 2002; Dietz \& Haurin, 2003). Increasing housing stability was another common theme that emerged from exisitng programs. Many of the programs had objectives to improve living conditions and ensuring housing stability for both owners and renters. Improving living conditions by assisting with renovations can improve housing stability because it reduces the risk of owners not paying their monthly payments due to large repair costs. Housing stability also allows people to remain in their homes as long as they need to or want to and financial assistance to improve spaces to accommodate for accessibility increases housing stability. Assisstance from all levels of governments was the third emerging theme. This is an important aspect in providing affordable homes for both renters and owners. Municipalities do not have the financial capacity to provide affordable ownership units for residents nor do they have the capacity to 
continously make improvements to exisitng structures. There is a need and responsibility of all levels of government to participate financially in alleviating the housing affordability issues in the GGHA.

These programs have demonstrated a good foundation and framework for guiding municipal policies and programs for increasing affordable housing, particularly affordable homeownership. Programs such as Ontario's Long-Term Affordable Housing Strategy and Peel's Housing and Homelessness Plan do not directly target affordable homeownership, but rather provide an overarching vision for improving affordable housing in general. These strategies and plans are guiding frameworks for local municipalities to create programs that pertain to their specific needs. Both of the non-profit organizations champion affordable homeownership, Habitat for Humanity and Options for Homes have different ways of assisting with down payments and providing viable options for households. Additionally, CMHC also provides a feasible option for down payment assistance in the form of a forgivable loan. These three programs are a gateway into homeownership and provide potential owners with the opportunity to bypass one of the largest barriers when making the decision to buy a home (Painter \& Redfearn, 2002; Dietz \& Haurin, 2003). The City of Mississauga Affordable Housing Program, although not completely procured, is definitely a valuable asset in improving affordable homeownership. This program has not only identified the affordable housing issues, but has plans to increase affordable housing options for all residents. 


\section{RECOMMENDATIONS}

Affordable homeownership is a major concern in Mississauga as well as other parts of the GGHA. Literature has suggested the benefits of having affordable housing and homeownership not only contribute to the quality of life of residents, but have greater socio-economic benefits. Urban containment policies have directed growth and dictated the types of dwellings that are likely to emerge in the future. This has contributed to pressures on both supply and demand on low-rise dwelling types, such as single-detached houses. The decreasing land supply encourages mid-density to high-density dwellings to accommodate for growth in the GGHA as well as meet policies requirements and targets.

The Province of Ontario has provided plans that act as a framework to guide municipalities to develop strategies to help them face the challenges of providing affordable housing locally, both rental and ownership. The GGHA is a unique part of Ontario and has very different attributes as far as growth in population and employment than the rest of Ontario. Similarly, the Region of Peel's policies and programs are intended to guide the Region in fostering livable, vibrant, complete communities. Improving rental affordability will minimize the gap between renters and owners and hopefully encourage more renters to become homeowners. Mississauga's Affordable Housing Program is a step in the right direction for mitigating the affordability issues that so many residents currently face. Moving into the next 20 years, it will become increasingly important to support affordable homeownership as age and household structures being transforming. The aging population and increased immigrant migration are two of the most susceptible household types to housing affordability issues. Over the next 20 years these two groups will make up a significant portion of the population in Mississauga.

This section provides some recommendations that the City of Mississauga should undertake to begin improving affordable homeownership issues. Some of these recommendations have been addressed throughout the procurement of Mississauga's Affordable Housing Program. They have been chosen to be recognized in this section because they are important and although these recommendations are directed and tailored for Mississauga, they can be used to guide other municipalities in improving affordable homeownership issues.

\subsection{Recommendation 1 - Vacant Land Inventory}


The City of Mississauga has an inventory of vacant lands within its boundaries. This inventory lists all the vacant lands, their zoning, the Official Plan designation, the size, and other important attributes. The City should identify areas of potential, where new housing developments could occur. Creating a map and an inventory of owners, zoning, and the potential highest and best use for each particular piece of property would allow the City to identify the potential areas of future development.

For example, one of the vacant lots is located in the Uptown Major Node area, is in a corridor and a major transit area. It is 3.30 ha, designated High Density in the Official Plan, zoned residential with permitted uses being apartment dwellings. The maximum height of part of the land is 25 storeys. This is a perfect example of one of the few greenfield spaces left in the city that could be used to facilitate affordable housing.

Mississauga should create an inventory of vacant land and analyze the zoning and OP designation to ensure that the land use assigned to each property will produce the highest and best use of the space.

\subsection{Recommendation 2 - Use Public Lands First}

Land prices are a huge barrier to producing affordable housing. The cost of the land is a huge determinant in overall selling price per square foot of properties. The City has already put forth a motion to use public land for affordable housing first. They have identified three ways that the municipality can do this:

1. Enter into a land lease

2. Donate land

3. Provide land below market value

(City of Mississauga, 2016).

The City should look at utilizing surplus lands to facilitate affordable housing. Additionally, they should look at existing buildings owned by the City that are in need of care. Looking at the opportunity to redevelop existing built form to increase their capacity and provide better quality homes for current residents and opening up more space of new residents. Additionally, The Centre for Urban Research and Land Development recently produced an interactive map of government owned public lands in the Greater Toronto/Hamilton Area (Ryerson University: Centre for Urban Research and Land Development, n.d.). This map identifies publicly owned lands from the Federal, Provincial and local 
Municipal governments as well as their local agency boards and commissions (Ryerson University: Centre for Urban Research and Land Development, n.d.). The map provides information about each site including, address, postal code, ownership, size and land use as well as other characteristic that describe the site (Ryerson University: Centre for Urban Research and Land Development, n.d.). Mississauga could use this inventory to begin their analysis on which properties would be ideal for increasing supply of affordable homeownership. The City could categorize these properties based on surplus lands or need to repair or redevelopment that could be leased, donated or sold at an affordable price as an incentive to increase affordable ownership units.

\subsection{Recommendation 3 - First Time Home Buyers Assistance}

Down payments are the biggest barriers and challenges that potential home buyers face (Painter \& Redfearn, 2002; Dietz \& Haurin, 2003). Both non-profit organizations discussed in this paper, Options for Homes and Habitat for Humanity as well as $\mathrm{CMHC}$ offer incentives and programs to help mitigate the burden of down payments. Through Mississauga's Affordable Housing Program and the support of all levels of government, providing assistance to help first time home buyers achieve homeownership, may alleviate some affordable issues. There are many residents that are in the rental market that live affordably; if there was assistance for a down payment some of these households could move into ownership where they may still be spending less than $30 \%$ of their income on housing costs, opening up other potential affordable units for other renters.

\subsection{Recommendation 4 - Education for Programs}

Education is an extremely important tool. Many of the programs offered by CMHC could really improve affordable housing. There is a lot of funding provided by the Federal and Provincial government that many households could take advantage of. The City of Mississauga should invest in creating educational programs to aid residents in understanding the programs that are available to them to help alleviate their housing affordability issues.

\subsubsection{Workshops}

Developing workshops to assist residents access funding for affordable housing will be a key part of improving the issue in Mississauga. Changing demographics increases the importance of education, as many households are comprised of recent immigrant they may not have the knowledge about 
mortgages and may require financial education, or older adults who need to plan for retirement and are not sure what the benefits of downsizing are. Some example workshops include:

- Program Eligibility - helping residents figure out what programs they are eligible for.

- Application Assistance - helping residents fill out applications and obtaining all the necessary information for their application.

- Financial education for those who do not understand mortgages or financing/refinancing homes.

- Importance of affordable housing - educate residents about the need for affordable housing and why it is important.

- Benefits of Homeownership - many people will rent their whole lives without knowing some of the benefits (and constraints) to homeownership, but a workshop on educating them can help households make informed decisions about their housing tenure.

- Second Unit Legalization - encouraging the legalization of second units in households and the importance of this to affordable housing. Additionally, workshops should provide residents with assistance in accomplishing this.

\subsubsection{Resource Tool Easy for Residents to Access}

Another way to increase education is to develop a tool, similar to the workshops, is to create an interactive tool to help residents understand the programs that are available to them. This tool could be on the City of Mississauga website and allows residents to filter out criteria that pertain to them and produce programs they would be eligible for.

\subsection{Recommendation 5 - Incentives for Developers to Build Affordable Housing}

Another way that Mississauga could improve affordable housing is to provide developers with incentives for building affordable housing. The City's Affordable Housing Program is looking into this. Similar to section 37 incentives, the City could provide developers with financial compensations and other zoning requirements in lieu of providing a certain percentage of affordable units within a building. The City should focus on providing incentives to developers that develop in medium- and high-density areas to optimize the number of affordable ownership units being developed. This is important as housing development will shift toward higher-density developments over the next 20 years.

\subsubsection{Reduced Fees}


Mississauga could reduce certain fees that increase development costs including, development charges, fees for changes in plan of subdivisions, or condominium after the initial base fee. Additionally, Mississauga has a Site Plan Control Bylaw in which all developments must have a Site Plan Approval, the cost of this could be reduced. By reducing some of the costs associated with development approvals, developers may be able to construct buildings with much lower soft costs, which decrease the overall cost of construction and hopefully decrease the price/square foot for potential purchasers.

\subsubsection{Reduced parking for developments close to transit corridors}

If developers are building high-density buildings within transit corridors, they could opt for less parking in place of providing a certain percentage of affordable units. This would be extremely useful for highdensity developments close to watercourses that make underground parking difficult or not possible.

\subsubsection{Reduced landscaping requirements}

Some zones in Mississauga zoning by-law require a large portion of the property to be landscaped (40\% in some areas), however the City could provide developers with the incentive to reduce this if they produced a certain percentage of affordable units.

\subsection{Recommendation 6 - Secondary Units}

Secondary Units are part of the city's Affordable Housing Program. They have replaced their previous bylaw about secondary units, called the Second Units Registration By-law (By-law 114-16). There is no registration fee which is an incentive for homeowners to legalize their second units. Second units not only decrease unaffordability/housing costs for current homeowners, but also increase supply of affordable units for renters. This should be one of the primary and immediate focuses of the city in providing affordable housing, because it exists and it can be an immediate solution to housing issues now.

\subsection{Recommendation 7 - Encourage Wood-frame Apartments in Medium-Density} Areas

Wood-frame construction costs a lot less than pored concrete. The Ontario Building Code has increased the number of floors from 4 to 6 that can be built using a wood-frame. This could provide potential for affordable ownership units in medium-density areas by reducing the construction costs of dwellings built up to 6 storeys. 


\subsection{Recommendation 8 - Focus on Low- and Moderate-income Households}

Mississauga has clearly identified that the majority of residents that suffer affordable housing issues are within Decile 1 and 6, these households are classified as low- and moderate-income households. This recommendation is to ensure that the Affordable Housing Program focus on the groups that are the most vulnerable. When increased supply of affordable ownership becomes available, the city needs to identify who has first priority. The City should recognize the households that have deep and severe housing affordability issues and ensure that these households have first priority when accessing available affordable ownership units.

Prioritizing households will help to alleviate some housing cost pressures, even if these households do not move into affordable housing (as defined by spending less than $30 \%$ of income) they move into housing that is more affordable than they were previously.

\subsection{Recommendation 9- Inclusionary Zoning}

As mentioned in the Policy section, Inclusionary Zoning received Royal Assent in December 2016 (Ministry of Municipal Affairs and Housing, 2017). This policy could shape the future of affordable homeownership in Mississauga and other municipalities within the GGHA. Inclusionary Zoning has the potential to increase the supply of affordable housing that serves the needs of low- to moderateincome households, it would create inclusive and integrated communities, and it would help meet local needs.

It is recommended that the City of Mississauga implement Inclusionary Zoning as a requirement for all new condominium developments to provide units that are affordable for low- to moderate-income households. This means that units should cost no more than $30 \%$ of households before-tax income and given that there is a huge potential for condominium development in Mississauga's future, this legislation will increase affordable housing. Additionally, Inclusionary Zoning will increase the supply of affordable units over time through gradual development of new condominiums, increasing the sustainability of affordable homeownership, even in housing prices continue to increase.

6.10. Recommendation 10 - Limited Equity Cooperatives 
Limited Equity Cooperatives are a form of affordable housing in a resident-controlled environment (We Own, 2003). This type of housing does not require individuals to have a mortgage on their unit.

Residents share purchase price and these shares entitle individuals to a long-term lease on a unit and a vote in cooperative government (We Own, 2003). Each individual is both a tenant through the lease with the corporation and an owner through stock ownership and participation in group governance (We Own, 2003). This affordable housing model, allows low- to moderate-income households purchase low cost shares and are guaranteed a unit for as long as they desire, so long as they adhere to the terms of their lease. It requires less capital than a down payment for a mortgage and allows residents with a voice (through a vote) in major decisions pertaining to the cooperative. It also serves as a sustainable, long-term solution to affordable housing. Sales of cooperative stocks are determined by a specific formula to ensure that units remain affordable for future and current residents (We Own, 2003). CMHC describes shared equity tenure as an easier and more accessible way for people with low incomes to access homeownership (Canada Mortgage and Housing Corporation, 2017).

This approach is recommended to the City of Mississauga, as many of the affordable housing issues are faced by low- to moderate-income households. Encouraging various affordable housing options, such as limited equity cooperatives will increase affordable housing in the city. It caters to residents who are willing to play an interactive role in managing and maintaining their residences while at the same time maintaining affordability. It requires shared responsibilities and liabilities of all members of the cooperative and is a feasible alternative to achieve affordable homeownership.

This recommendation also addresses a need for change in legislation and financial responsibility of all levels of government. Aging population and changing demographics means a need to change types of dwellings including providing affordable units for households that may have a fixed income (retired households). A change in legislation and an increased financial responsibility of all levels of government to support housing options such as limited-equity cooperatives will allow for more efficient and specific funding solutions to alleviate affordable housing issues. 


\section{CONCLUSIONS}

This paper has focused on the importance of affordable housing. In particular, it addressed literature that supports affordable homeownership and the benefits that are associated with ownership. Homeownership comprises a household's largest investment and it is often the main form of savings (Painter \& Redfearn, 2002; Hou, 2010; McKee, 2012; Begley, 2017). This research is important in the Planning realm because planning plays a key role in ensuring high quality of life for everyone. This paper explores Provincial and Regional planning policies that guide and act as a framework for local municipal planning. It is intended to enlighten readers about current affordable housing issues and of the existing programs that intend to alleviate and improve housing affordability issues, particularly affordable homeownership issues.

The City of Mississauga was chosen as the subject of this paper because it is one of the most populous cities in Canada and has a diverse population and a wide range of housing types. It is an urban area outside the main urban centre that is Toronto, and although there are pockets that resemble traditional suburban life, reliant on cars, it is widely connected by public transportation and continues to improve transit to connect the entire city. The City of Mississauga has gathered data, analyzed it and has recognized that there is a housing affordability issue. The City is currently developing a plan to address these issues and have identified the major areas of concern.

The recommendations provided in this paper are tailored to the City of Mississauga, but have the ability to be applied to other municipalities in the GGHA that are also facing similar affordable homeownership issues. Although housing affordability issues are unique to their local context, municipalities within the Greater Golden Horseshoe Area are similar in that they are affected by urban containment policies, natural environments and huge changes in population growth, age and structure that create affordability issues not faced in other parts of the Province. These recommendations are transient and can be tailored to local needs to address housing affordability issue.

The intent of this paper was to create an understanding of affordable housing, particularly homeownership. The benefits that are associated with owning a home and how improving homeownership could create a butterfly effect that has a positive impact on housing in general. This paper also recognized the housing trends in Canada, Ontario and Mississauga, and used this 
information to help inform and justify that there is in fact an affordability issue in the Greater Golden Horseshoe. The recommendations provide viable options for alleviating current housing affordability issues and increasing the supply of affordable units. Current policies, plans and programs provide some solutions to these issues, the recommendations offer an addition to existing solutions and provide options for the future of affordable housing in municipalities within the GGHA. Owning a home is becoming increasingly unaffordable and this paper intended to provide solutions to facilitate sustainable housing options for Mississauga residents. 


\section{Appendix A: Tables for Core Housing Need}

\begin{tabular}{|c|c|c|c|c|c|c|c|c|c|c|}
\hline \multicolumn{11}{|l|}{ Canada } \\
\hline & \multicolumn{2}{|c|}{$\begin{array}{c}2011 \\
(\text { GNR }=26.1 \%)\end{array}$} & \multicolumn{2}{|c|}{2006} & \multicolumn{2}{|c|}{2001} & \multicolumn{2}{|c|}{1996} & \multicolumn{2}{|c|}{1991} \\
\hline & $\#$ & $\%$ & $\#$ & $\%$ & $\#$ & $\%$ & $\#$ & $\%$ & $\#$ & $\%$ \\
\hline $\begin{array}{l}\text { All Private } \\
\text { Households }\end{array}$ & $13,319,250$ & & $12,437,470$ & & $11,562,975$ & & $10,820,050$ & & $10,018,265$ & \\
\hline $\begin{array}{l}\text { Households } \\
\text { Excluded from } \\
\text { Examination } \\
\text { for Core } \\
\text { Housing Need } \\
\text { in HiCO }\end{array}$ & 856,815 & & 671,325 & & 757,360 & & 792,210 & & 646,535 & \\
\hline $\begin{array}{l}\text { Households } \\
\text { Examined for } \\
\text { Core Housing } \\
\text { Need in HiCO }\end{array}$ & $12,462,435$ & 100.0 & $11,766,145$ & 100.0 & $10,805,615$ & 100.0 & $10,027,840$ & 100.0 & $9,371,730$ & 100.0 \\
\hline $\begin{array}{l}\text { Living } \\
\text { in Acceptable } \\
\text { Housing }\end{array}$ & $8,619,500$ & 69.2 & $8,177,025$ & 69.5 & $7,556,660$ & 69.9 & $6,798,750$ & 67.8 & $6,532,510$ & 69.7 \\
\hline $\begin{array}{l}\text { Living in } \\
\text { Housing Below } \\
\text { Standards }\end{array}$ & $3,842,935$ & 30.8 & $3,589,120$ & 30.5 & $3,248,955$ & 30.1 & $3,229,090$ & 32.2 & $2,839,225$ & 30.3 \\
\hline $\begin{array}{l}\text { Not in core } \\
\text { housing need }\end{array}$ & $2,290,790$ & 18.4 & $2,094,725$ & 17.8 & $1,763,615$ & 16.3 & $1,661,910$ & 16.6 & $1,569,240$ & 16.7 \\
\hline $\begin{array}{l}\text { In core } \\
\text { housing need }\end{array}$ & $1,552,145$ & 12.5 & $1,494,395$ & 12.7 & $1,485,335$ & 13.7 & $1,567,180$ & 15.6 & $1,269,980$ & 13.6 \\
\hline $\begin{array}{l}\text { Aboriginal } \\
\text { households }\end{array}$ & 503,160 & 100.0 & 401,145 & 100.0 & 297,285 & 100.0 & 218,310 & 100.0 & N.A. & N.A. \\
\hline $\begin{array}{l}\text { Not in core } \\
\text { housing need }\end{array}$ & 407,380 & 81.0 & 319,330 & 79.6 & 226,020 & 76.0 & 152,225 & 69.7 & N.A. & N.A. \\
\hline $\begin{array}{l}\text { In core } \\
\text { housing need }\end{array}$ & 95,780 & 19.0 & 81,810 & 20.4 & 71,265 & 24.0 & 66,090 & 30.3 & N.A. & N.A. \\
\hline Owners & $8,712,335$ & 100.0 & $8,158,120$ & 100.0 & $7,229,665$ & 100.0 & $6,494,030$ & 100.0 & $5,925,460$ & 100.0 \\
\hline $\begin{array}{l}\text { Not in core } \\
\text { housing need }\end{array}$ & $8,149,570$ & 93.5 & $7,645,475$ & 93.7 & $6,755,815$ & 93.4 & $6,047,820$ & 93.1 & $5,571,025$ & 94.0 \\
\hline $\begin{array}{l}\text { In core } \\
\text { housing need }\end{array}$ & 562,765 & 6.5 & 512,645 & 6.3 & 473,845 & 6.6 & 446,210 & 6.9 & 354,440 & 6.0 \\
\hline Renters & $3,750,105$ & 100.0 & $3,608,025$ & 100.0 & $3,575,950$ & 100.0 & $3,533,810$ & 100.0 & $3,446,270$ & 100.0 \\
\hline $\begin{array}{l}\text { Not in core } \\
\text { housing need }\end{array}$ & $2,760,720$ & 73.6 & $2,626,275$ & 72.8 & $2,564,465$ & 71.7 & $2,412,840$ & 68.3 & $2,530,725$ & 73.4 \\
\hline $\begin{array}{l}\text { In core } \\
\text { housing need }\end{array}$ & 989,380 & 26.4 & 981,750 & 27.2 & $1,011,490$ & 28.3 & $1,120,975$ & 31.7 & 915,545 & 26.6 \\
\hline$\frac{\text { Non-Senior }}{\text { households }}$ & $9,574,220$ & 100.0 & $9,192,300$ & 100.0 & $8,473,565$ & 100.0 & $7,928,495$ & 100.0 & $7,527,905$ & 100.0 \\
\hline $\begin{array}{l}\text { Not in core } \\
\text { housing need }\end{array}$ & $8,416,370$ & 87.9 & $8,067,765$ & 87.8 & $7,381,440$ & 87.1 & $6,734,695$ & 84.9 & $6,596,765$ & 87.6 \\
\hline
\end{tabular}




\begin{tabular}{|l|l|l|l|l|l|l|l|l|l|l|}
\hline $\begin{array}{l}\text { In core } \\
\text { housing need }\end{array}$ & $1,157,850$ & 12.1 & $1,124,535$ & 12.2 & $1,092,135$ & 12.9 & $1,193,800$ & 15.1 & 931,140 & 12.4 \\
\hline $\begin{array}{l}\text { Senior } \\
\text { Households }\end{array}$ & $\mathbf{2 , 8 8 8 , 2 1 5}$ & $\mathbf{1 0 0 . 0}$ & $\mathbf{2 , 5 7 3 , 8 4 5}$ & $\mathbf{1 0 0 . 0}$ & $\mathbf{2 , 3 3 2 , 0 5 0}$ & $\mathbf{1 0 0 . 0}$ & $\mathbf{2 , 0 9 9 , 3 4 5}$ & $\mathbf{1 0 0 . 0}$ & $\mathbf{1 , 8 4 3 , 8 2 5}$ & $\mathbf{1 0 0 . 0}$ \\
\hline $\begin{array}{l}\text { Not in core } \\
\text { housing need }\end{array}$ & $2,493,920$ & 86.3 & $2,203,985$ & 85.6 & $1,938,840$ & 83.1 & $1,725,965$ & 82.2 & $1,504,985$ & 81.6 \\
\hline $\begin{array}{l}\text { In core } \\
\text { housing need }\end{array}$ & 394,295 & 13.7 & 369,860 & 14.4 & 393,205 & 16.9 & 373,385 & 17.8 & 338,840 & 18.4 \\
\hline $\begin{array}{l}\text { Family } \\
\text { households }\end{array}$ & $\mathbf{8 , 6 4 0 , 5 8 5}$ & $\mathbf{1 0 0 . 0}$ & $\mathbf{8 , 2 8 5 , 2 0 0}$ & $\mathbf{1 0 0 . 0}$ & $\mathbf{7 , 7 0 1 , 6 8 0}$ & $\mathbf{1 0 0 . 0}$ & $\mathbf{7 , 1 7 5 , 6 3 5}$ & $\mathbf{1 0 0 . 0}$ & $\mathbf{6 , 8 0 4 , 5 1 5}$ & $\mathbf{1 0 0 . 0}$ \\
\hline $\begin{array}{l}\text { Not in core } \\
\text { housing need }\end{array}$ & $7,867,000$ & 91.0 & $7,524,465$ & 90.8 & $6,947,145$ & 90.2 & $6,339,945$ & 88.4 & $6,185,735$ & 90.9 \\
\hline $\begin{array}{l}\text { In core } \\
\text { housing need }\end{array}$ & 773,590 & 9.0 & 760,730 & 9.2 & 754,535 & 9.8 & 835,690 & 11.6 & 618,775 & 9.1 \\
\hline $\begin{array}{l}\text { Non-family } \\
\text { households }\end{array}$ & $\mathbf{3 , 8 2 1 , 8 5 0}$ & $\mathbf{1 0 0 . 0}$ & $\mathbf{3 , 4 8 0 , 9 5 0}$ & $\mathbf{1 0 0 . 0}$ & $\mathbf{3 , 1 0 3 , 9 3 5}$ & $\mathbf{1 0 0 . 0}$ & $\mathbf{2 , 8 5 2 , 2 1 0}$ & $\mathbf{1 0 0 . 0}$ & $\mathbf{2 , 5 6 7 , 2 1 5}$ & $\mathbf{1 0 0 . 0}$ \\
\hline $\begin{array}{l}\text { Not in core } \\
\text { housing need }\end{array}$ & $3,043,290$ & 79.6 & $2,747,285$ & 78.9 & $2,373,135$ & 76.5 & $2,120,715$ & 74.4 & $1,916,020$ & 74.6 \\
\hline $\begin{array}{l}\text { In core } \\
\text { housing need }\end{array}$ & 778,555 & 20.4 & $\mathbf{7 3 3 , 6 6 5}$ & 21.1 & 730,800 & 23.5 & 731,495 & 25.6 & 651,200 & 25.4 \\
\hline
\end{tabular}

Table 3 Canada: Core Housing Need

Source: CMHC (Census-based and NHS-based housing indicators and data), Statistics Canada (Census of Canada, National Housing Survey)

\section{Ontario}

\begin{tabular}{|c|c|c|c|c|c|c|c|c|c|c|}
\hline & \multicolumn{2}{|c|}{$\begin{array}{c}2011 \\
(\text { GNR }=27.1 \%)\end{array}$} & \multicolumn{2}{|c|}{2006} & \multicolumn{2}{|c|}{2001} & \multicolumn{2}{|c|}{1996} & \multicolumn{2}{|c|}{1991} \\
\hline & \# & $\%$ & $\#$ & $\%$ & $\#$ & $\%$ & $\#$ & $\%$ & $\#$ & $\%$ \\
\hline All Private Households & $4,886,655$ & & $4,555,025$ & & $4,219,415$ & & $3,924,510$ & & $3,638,360$ & \\
\hline $\begin{array}{l}\text { Households Excluded from } \\
\text { Examination for Core } \\
\text { Housing Need in HiCO }\end{array}$ & 286,600 & & 235,880 & & 237,870 & & 244,195 & & 204,460 & \\
\hline $\begin{array}{l}\text { Households Examined } \\
\text { for Core Housing Need in } \\
\text { HiCO }\end{array}$ & $4,600,055$ & 100.0 & $4,319,145$ & 100.0 & $3,981,545$ & 100.0 & $3,680,315$ & 100.0 & $3,433,900$ & 100.0 \\
\hline $\begin{array}{l}\text { Living in Acceptable } \\
\text { Housing }\end{array}$ & $3,092,270$ & 67.2 & $2,896,670$ & 67.1 & $2,723,375$ & 68.4 & $2,422,530$ & 65.8 & $2,360,560$ & 68.7 \\
\hline $\begin{array}{l}\text { Living in Housing Below } \\
\text { Standards }\end{array}$ & $1,507,785$ & 32.8 & $1,422,475$ & 32.9 & $1,258,170$ & 31.6 & $1,257,785$ & 34.2 & $1,073,335$ & 31.3 \\
\hline Not in core housing need & 890,850 & 19.4 & 794,940 & 18.4 & 658,510 & 16.5 & 663,540 & 18.0 & 665,305 & 19.4 \\
\hline In core housing need & 616,935 & 13.4 & 627,535 & 14.5 & 599,655 & 15.1 & 594,250 & 16.1 & 408,035 & 11.9 \\
\hline Aboriginal households & 132,195 & 100.0 & 101,225 & 100.0 & 72,310 & 100.0 & 50,245 & 100.0 & N.A. & N.A. \\
\hline Not in core housing need & 108,545 & 82.1 & 82,290 & 81.3 & 57,415 & 79.4 & 36,355 & 72.4 & N.A. & N.A. \\
\hline In core housing need & 23,650 & 17.9 & 18,940 & 18.7 & 14,895 & 20.6 & 13,885 & 27.6 & N.A. & N.A. \\
\hline Owners & $3,325,095$ & 100.0 & $3,109,700$ & 100.0 & $2,748,870$ & 100.0 & $2,410,615$ & 100.0 & $2,212,110$ & 100.0 \\
\hline Not in core housing need & $3,085,190$ & 92.8 & $2,880,790$ & 92.6 & $2,547,545$ & 92.7 & $2,237,735$ & 92.8 & $2,096,600$ & 94.8 \\
\hline In core housing need & 239,905 & 7.2 & 228,910 & 7.4 & 201,330 & 7.3 & 172,880 & 7.2 & 115,505 & 5.2 \\
\hline Renters & $1,274,955$ & 100.0 & $1,209,445$ & 100.0 & $1,232,670$ & 100.0 & $1,269,700$ & 100.0 & $1,221,790$ & 100.0 \\
\hline Not in core housing need & 897,925 & 70.4 & 810,825 & 67.0 & 834,345 & 67.7 & 848,330 & 66.8 & 929,260 & 76.1 \\
\hline In core housing need & 377,030 & 29.6 & 398,625 & 33.0 & 398,330 & 32.3 & 421,365 & 33.2 & 292,530 & 23.9 \\
\hline
\end{tabular}




\begin{tabular}{|c|c|c|c|c|c|c|c|c|c|c|}
\hline Von- & 0 & 100.0 & 80 & 100.0 & 45 & 10 & 2,8 & 10 & 5 & 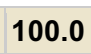 \\
\hline ot in core housing & 0 & 86.8 & 0 & 86.2 & 50 & 86.2 & 30 & 84. & 5 & 89.3 \\
\hline$d$ & & & & 13.8 & & 13.8 & & 15.3 & & 10.7 \\
\hline en & & 1 & 70 & 0 & & 0 & U & 0 & 0 & 00.0 \\
\hline ot $\mathrm{i}$ & 0 & 86.1 & 5 & 820 & 702,635 & 3 & 0 & 8 & 5 & 32 \\
\hline $\mathrm{n} \mathrm{co}$ & & 13.9 & & 17.1 & & 19.7 & & 19.1 & & 16.8 \\
\hline an & & 1 & 0 & 1 & & 0 & 15 & 0 & & .0 \\
\hline ot & 65 & 89.6 & 10 & 88.7 & 460 & 88.4 & 100 & 87.1 & 35 & 91.8 \\
\hline 0 & & 10.4 & & 11.3 & & 11.6 & & 12.9 & & . \\
\hline Jon & & 100 & 665 & 100 & 5 & 100.0 & 2 & 00.0 & & 0 \\
\hline Jot ir & $1,006,860$ & 78.8 & 878,705 & 76.6 & 782 & 75.1 & 736,965 & 75.0 & 700 & 77.8 \\
\hline cor & 70,265 & 21 & 97 & 3.4 & 260 , & 24.9 & 10 & 25.0 & 00,160 & 22.2 \\
\hline
\end{tabular}

Table 4 Ontario: Core Housing Need

Sources: CMHC (Census-based and NHS-based housing indicators and data), Statistics Canada (Census of Canada, National Housing Survey) 


\section{Appendix B: Policy}

\section{Proposed Growth Plan for the Greater Golden Horseshoe, 2016}

\subsubsection{Housing}

1. Upper-and single-tier municipalities, in consultation with lower-tier municipalities, the Province and other appropriate stakeholders, will each develop a housing strategy that:

a. Aligns with applicable housing and homelessness plans required under the Housing Services Act, 2011;

b. Identifies policies for official plans, including affordable housing targets, that address the needs for all residents, including through affordable ownership housing and rental housing; and

c. Plans for a diverse range of housing types and densities, including secondary suites, to support the achievement of the minimum intensification and density targets in this Plan, as well as the other policies of this Plan.

2. Notwithstanding policy 1.4.1 of the PPS, 2014, to provide for a range and mix of housing types and densities municipalities will:

a. Plan to accommodate forecasted growth to the horizon of this Plan;

b. Plant to achieve the minimum intensification and density targets in the Plan;

c. Consider the range of housing types and densities of the existing housing stock; and

d. Plan to diversify their overall housing supply to achieve complete communities

\section{Region of Peel Official Plan}

5.8 Housing

5.8.2 General Policies

It is the policy of Regional Council to:

5.8.2.1 Maintain jointly, with the area municipalities, a supply of designated land for new residential development, redevelopment and residential intensification in Peel Region in accordance with projected requirements an available land resources.

a. Maintain at all times the ability to accommodate residential growth for a minimum of ten years through residential intensification and redevelopment and lands which are designated and available for residential development; and

b. Maintain at all times where new development is to occur, land with servicing capacity sufficient to provide at least a three year supply of residential units available through land suitably zoned to facilitate residential intensification and redevelopment and land in draft approved and registered plans

5.8.2.2 Encourage the area municipalities, while taking into account the characteristics of existing communities, to establish policies in their official plans which 
support:

a. Residential redevelopment in appropriate areas that have sufficient existing or planned infrastructure; and

b. Cost-effective development standards for new residential development, redevelopment, and intensification

5.8.2.3 Encourage and support the efforts by the area municipalities to plan for a range of densities and forms of housing affordable to all households, including low and moderate income households, enabling all Peel residents to remain in their communities

5.8.2.4 Assist public agencies at the federal, provincial and area municipal levels in identifying and maintaining an inventory of available public lands and building suitable for housing for low and moderate income households in Peel Region

5.8.2.5 Support the initiatives of the area municipalities in the construction and retention of rental housing

5.8.2.6 Collaborate with the area municipalities and other stakeholders such as the conservation authorities, the building and development industry, and landowners to encourage new residential development, redevelopment, and intensification in support of Regional and area municipal official plan policies promoting compact forms of development and residential intensification.

5.8.2.7 Develop an implementation plan, in collaboration with human services stakeholders, for the Regional Housing Strategy by setting priorities and timeframes among various housing needs of residents and identify and implement programs and actions to address these needs.

5.8.2.8 Monitor and evaluate activities undertaken in support of the Regional Housing Strategy to revise and set new priorities on an ongoing basis as the housing needs of Peel residents change.

5.8.2.9 Evaluate the need to update the Regional Housing Strategy in conjunction with future Regional Official Plan reviews.

5.8.2.10 Encourage the area municipalities to establish minimum new housing unit targets that are affordable in secondary plans where appropriate, to ensure a diverse $\mathrm{mx}$ of housing type and tenure.

5.8.2.11 Work with area municipalities to educate the general public about the need for and benefits of compact housing development and residential intensification.

5.8.2.12 Collaborate with the area municipalities to implement annual minimum new housing unit targets for Peel as shown in Table 5 . 
5.8.2.13 Collaborate with the area municipalities to implement annual minimum new housing unit targets (Table 5).

5.8.2.14 Review and update, jointly with the area municipalities, annual minimum new housing unit targets as shown in Table and Figure based on most recent Census of Canada results and other relevant sources.

\begin{tabular}{|l|c|c|c|c|}
\hline & $\begin{array}{c}\text { Social } \\
\text { Housing }\end{array}$ & $\begin{array}{c}\text { Affordable } \\
\text { Rental }\end{array}$ & $\begin{array}{c}\text { Market } \\
\text { Rental and } \\
\text { Affordable } \\
\text { Ownership }\end{array}$ & $\begin{array}{c}\text { Market } \\
\text { Ownership }\end{array}$ \\
\hline Peel & $17 \%$ & $3 \%$ & $35 \%$ & $45 \%$ \\
\hline Mississauga & $18 \%$ & $3 \%$ & $34 \%$ & $45 \%$ \\
\hline
\end{tabular}

Table 5 Annual Minimum New Housing Unit Targets in Peel and Mississauga Source: Region of Peel Official Plan

\subsubsection{Supply of Affordable Housing}

\subsubsection{Policies}

It is the policy of Regional Council to:

5.8.3.2.1 Explore, in collaboration with the area municipalities, the feasibility of implementing incentives such as waivers, deferrals, or grants in-lieu of development charges, other municipal planning and building fees and charges, and regional property taxes to promote the development of affordable housing.

5.8.3.2.2 Work with the area municipalities to explore opportunities to coordinate the fast-tracking of planning approvals for affordable housing projects.

5.8.3.2.3 Encourage the area municipalities to develop alternative development and design standards, where appropriate, to encourage affordable housing development. Examples include reduced setbacks, narrower lot sizes, reduced road allowance, cash-in-lieu of parking, reduced parking standards, and onstreet parking.

5.8.3.2.4 Encourage the area municipalities to add a density bonusing provision in their respective official plans and develop detailed implementation guidelines and protocols.

5.8.3.2.5 Advocate to the Province to explicitly provide municipalities the authority to use inclusionary zoning as a tool to require affordable housing.

5.8.3.2.6 Encourage and support the area municipal official plans to permit secondary suites in new and existing residential development, redevelopment and intensification while ensuring compliance with provincial legislation, plans and municipal standards 
5.8.3.2.7 Encourage the area municipalities to explore the legalization of existing secondary suites to ensure compliance with health and safety standards

5.8.3.2.8 Work with the area municipalities to promote secondary suites through the development of educational brochures and information

5.8.3.2.9 Give priority to the development of affordable housing on surplus Regional municipal property while ensuring the goals, objectives, and policies of this Plan and the area municipal official plans are adhered to.

5.8.3.2.10 Encourage the area municipalities to give priority to sell or lease surplus municipal properties for the development of affordable housing while ensuring the goals, objectives and policies of this Plan and the area municipal official plans are adhered to.

5.8.3.2.11 Encourage residential development, redevelopment and intensification to include an affordable housing component by promoting incentives or funding from different levels of government.

5.8.3.2.12 Encourage community agencies and landowners of suitably sized sites to develop affordable housing

\section{City of Mississauga Official Plan}

7.0 Complete Communities

7.2 Housing

7.2.1 Mississauga will ensure that housing is provided in a manner that maximizes the use of community infrastructure and engineering services, while meeting the housing needs and preferences of Mississauga residents.

7.2.2 Mississauga will provide opportunities for:

a. The development of a range of housing choices in terms of type, tenure and price;

b. The production of a variety of affordable dwelling types for both the ownership and rental markets; and

c. The production of housing for those with special needs, such as housing for the elderly and shelters.

7.2.3 When making planning decisions, Mississauga will ensure that housing is provided in a manner that fully implements the intent of the Provincial and Regional housing policies.

7.2.4 Mississauga will ensure that the quality a quantity of the existing housing stock is maintained.

7.2.5 The onus will be placed on the applicant/developer to address Provincial and Regional housing requirements. 
7.2.6 Mississauga will consider the contribution that can be made to current housing needs by housing programs of other levels of government that will seek to maximize the use of those programs that meet the City's housing objectives.

7.2.7 Mississauga will directly assist all levels of government in the provision of rental housing by:

a. Supporting the efforts of the Regional and other local not for profit housing organizations in providing low and moderate income rental housing and accommodation for those with special needs;

b. Assisting the development of new rental units through the promotion of, and participation in, programs aimed at producing rental housing; and

c. Supporting the preservation of the rental housing stock.

7.2.8 Design solutions that support housing affordability while maintaining appropriate functional and aesthetic quality will be encouraged.

7.2.9 The provision of housing that meets the needs of young adults, older adults and families will be encouraged in the Downtown, Major Nodes and Community Nodes.

7.2.10 Mississauga will encourage the Region to provide social housing in appropriate locations to meet the needs of the local population.

7.2.11 Mississauga will work with the Region to develop a housing strategy that will establish and implement affordable housing targets

7.2.12 Conversion of residential rental properties to a purpose of other than the purpose of a residential rental property, or the demolition of residential rental properties exceeding six dwellings unit will not be permitted if it adversely affects the supply of affordable rental housing as determined by affordable housing targets and rental vacancy rates. 


\section{REFERENCES}

Aaronson, D. (2000). A Note on the Benefits of Homeownership. Journal of Urban Economics(47), 356369 .

Begley, J. (2017). Legacies of homeownership: Housing wealth and bequests. Journal of Housing Economics, 37-50.

Canada Mortgage and Housing Coporation. (2017). Affordable Housing Programs in Ontario. Retrieved from Canada Mortgage and Housing Corportation: https://www.cmhcschl.gc.ca/en/inpr/afhoce/fuafho/iah/afhopracca/afhopracca_oog.cfm

Canada Mortgage and Housing Corporation. (2014). Canadian Housing Oberserver 2014 with a feature on Housing Affordability and Need.

Canada Mortgage and Housing Corporation. (2014). Housing in Canada Online. Retrieved from Canada Mortgage and Housing Corporation: http://cmhc.beyond2020.com/HiCOControlCounts_EN.html\#_Ontario

Canada Mortgage and Housing Corporation. (2014). Housing in Canada Online - Reference Counts and the Definition of CMHC's Core Housing Need Universe. Retrieved from Canada Mortgage and Housing Corporation: http://cmhc.beyond2020.com/HiCOControlCounts_EN.html

Canada Mortgage and Housing Corporation. (2014). Investment in Affordable Housing for Ontario (2014 Extension) Program Guidelines. Retrieved from Ministry of Municipal Affairs and Housing: http://www.mah.gov.on.ca/AssetFactory.aspx?did=12338

Canada Mortgage and Housing Corporation. (2016, December 21). 12.7\% of Urban Households were in Core Housing Need in 2014. Retrieved February 27, 2017, from Canada Mortgage and Housing Corporation: https://www.cmhcschl.gc.ca/en/hoficlincl/observer/observer_110.cfm?obssource=observeren\&obsmedium=link\&obscampaign=obs-20161221-urban-core-housing-need

Canada Mortgage and Housing Corporation. (2016). Housing Market Outlook Canada Edition.

Canada Mortgage and Housing Corporation. (2016). Housing Market Outlook Ontario Region Highlights.

Canada Mortgage and Housing Corporation. (2016). What Is Core Housing Need? Retrieved from Canada Mortgage and Housing Corporation: https://www.cmhc-

schl.gc.ca/en/hoficlincl/observer/observer_044.cfm

Canada Mortgage and Housing Corporation. (2017). Housing Now Tables. Canada.

Canada Mortgage and Housing Corporation. (2017). Housing Tables Now. Ontario Region.

Canada Mortgage and Housing Corporation. (2017, February 16). Securitization. Retrieved from Canada Mortgage and Housing Corportation: https://www.cmhcschl.gc.ca/en/corp/about/whwedo/whwedo_003.cfm

Canada Mortgage and Housing Corporation. (2017). Shared Equity. Retrieved from Canada Mortgage and Housing Corporation: https://www.cmhcschl.gc.ca/en/inpr/afhoce/afhoce/afhostcast/afhoid/fite/sheq/eqco_oo2.cfm

Canada Mortgage and Housing Corporation. (2017, February 16). What CMHC Does. Retrieved from Canada Mortgage and Housing Corporation: https://www.cmhcschl.gc.ca/en/corp/about/whwedo/index.cfm

Canada Mortgage and Housing Corporation. (n.d.). Affordable Housing Initiative . Retrieved from Canada Mortgage and Housing Corporation: https://www.cmhcschl.gc.ca/en/inpr/afhoce/fias/fias_015.cfm

Canada Mortgage and Housing Corporation. (n.d.). Governance. Retrieved March 2, 2017, from Canada Mortgage and Housing Corporation: https://www.cmhcschl.gc.ca/en/corp/about/cogo/index.cfm 
Canada Mortgage and Housing Corporation. (n.d.). History of CMHC. Retrieved March 2, 2017, from Canada Mortgage and Housing Corporation: https://www.cmhcschl.gc.ca/en/corp/about/hi/index.cfm

Canada Mortgage and Housing Corportion. (2014). Housing in Canada Online - Definitions of Variables. Retrieved from Canada Mortgage and Housing Corporation: http://cmhc.beyond2020.com/HiCODefinitions_EN.html\#_Core_Housing_Need_Status

Cheung, C. (2014). Deconstructing Canada's housing markets: finance, affordability and urban sprawl . OECD Economics Department Working Papers, 1145.

City of Mississauga. (2002). 2001 Census Update Martial Status, Households, Families and Housing. Planning and Building Department, Mississauga.

City of Mississauga. (2004, February). Mississauga: The Evolution of a City. Retrieved from City of Mississauga: http://www5.mississauga.ca/research_catalogue/C-9_eiHisbrochure_fin_a2.pdf

City of Mississauga. (2012). 2011 Census Results Households, Families, Marital Status \& Housing. Planning and Building Department, Mississauga.

City of Mississauga. (2013). 2011 Census Results, Office \& Residental Directories 2013. City of Mississauga, Planning and Building Department, Mississauga.

City of Mississauga. (2013). Long-Range Forecasts City of Mississauga 2011-2051. Planning and Building Department. Mississauga: Hemson Consulting.

City of Mississauga. (2014). 2011 Census Results National Household Survey. Planning and Building Department. Mississauga: City of Mississauga.

City of Mississauga. (2014). City of Mississauga Age Structure Forecast 2011-2041. Planning and Building Department, Mississauga.

City of Mississauga. (2015). City of Mississauga Official Plan. City of Mississauga, City Wide Planning, Mississauga.

City of Mississauga. (2016). Affordable Housing Program Housing Gap Assessment. Mississauga.

City of Mississauga. (2016). Corporate Report - Affordable Housing Program: Public Land for Housing First. Planning and Building, Mississauga.

City of Mississauga. (2016). Corporate Report Comments on National Housing Strategy. Planning and Building, Mississauga.

City of Mississauga. (2016). Understanding the Cost Incentives. City of Mississauga Affordable Housing Program. Mississauga: NBLC.

City of Mississauga. (n.d.). Affordable Housing Program. Retrieved from City of Mississauga: http://www.mississauga.ca/portal/residents/affordablehousingprogram

City of Mississauga. (n.d.). History of Mississauga. Retrieved from City of Mississauga: http://www5.mississauga.ca/rec\&parks/websites/museums/pdfs/history_of_mississauga.pdf

City of Mississauga. (n.d.). Property Taxes. Retrieved February 24, 2017, from City of Mississauga: http://www.mississauga.ca/portal/cityhall/propertytaxbill

City of Mississauga. (n.d.). Second Units. Retrieved from City of Mississauga: http://www.mississauga.ca/portal/residents/housingchoicessecondunits

Cox, W., \& Pavletich, H. (2016). 13th Annual Demographia International Husing Affordability Survey: 2017. Demographia \& Performance Urban Planning.

Dietz, R. D., \& Haurin, D. R. (2003). The social and private micro-level consequences of homeownership. Journal of Urban Economics(54), 401-450.

Dreier, P., \& Hulchanski, D. J. (1993). The Role of Nonprofit Housing in Canada and the United States: Some Comparisons. Housing Policy Debate, 4(1), 43-80.

Green, R. K., \& White, M. J. (1997). Measuring the Benefits of Homeowning: Effects on Children. Journal of Urban Economics(41), 441-441. 
Habitat for Humanity. (n.d.). ABOUT THE RESTORE. Retrieved from Habitat for Humanity ReStore: http://www.hfhrestore.com/

Habitat for Humanity GTA. (2014). About Habitat for Humanity GTA. Retrieved from Habitat for Humanity GTA: http://www.habitatgta.ca/about-us.html

Habitat for Humanity Halton-Mississauga. (n.d.). Learn more. Retrieved from Habitat for Humanity Halton-Mississauga: http://www.habitatgta.ca/about-us.html

Hou, F. (2010). Homeownership over the life course of Canadians: evidence from Canadian censuses of population. Statistics Canada. Ottawa: Statistics Canada.

Hulchanski, D. J. (2006). What Factors Shape Canadian Housing Policy? The Intergovernmental Role in Canada's Housing System. In R. Young, \& C. Leuprecht, The State of the Federation 2004. Municipal - Federal - Provincial Relations in Canada (pp. 221-247). Montreal, Kingston, London, Ithaca.

Investopedia. (2017, February 16). Debt-To-Income Ratio. Retrieved from Investopedia: http://www.investopedia.com/terms/d/dti.asp

Investopedia. (2017, February 16). Loan-To-Value Ratio. Retrieved from Investopedia: http://www.investopedia.com/terms///loantovalue.asp

Investopedia. (2017, February 16). Overvalued. Retrieved from Investopedia: http://www.investopedia.com/terms/o/overvalued.asp

Investopedia. (2017). Repeat Sales Index. Retrieved from Investopedia: http://www.investopedia.com/terms/r/repeatsales-method.asp

McKee, K. (2012, September). Young People, Homeownership and Future Wealth. Housing Studies, $27(6), 853-862$.

Ministry of Municipal Affairs and Housing. (2016). Proposed Greenbelt Plan, 2016.

Ministry of Municipal Affairs and Housing. (2016). Proposed Growth Plan for the Greater Golden Horseshoe, 2016.

Ministry of Municipal Affairs and Housing. (2017, January 24). Inclusionary Zoning. Retrieved from Ministry of Municipal Affairs and Housing: http://www.mah.gov.on.ca/Page1379o.aspx

Mississauga Real Estate Board. (n.d.). Sales by Category. Retrieved from Mississauga Real Estate Board: http://creastats.crea.ca/miss/mlso2_category.html

Mississauga Real Estate Board. (n.d.). Sales by Price Range. Retrieved from Mississauga Real Estate Board: http://creastats.crea.ca/miss/mlso3_price.html

Nelson, A. C. (n.d.). Urban Containment American Style: A Preliminary Assessment. In Urban Sprawl in Western Europe and the USA.

Options for Homes. (2016). How it Works. Retrieved from Options for Homes: http://www.optionsforhomes.ca/how_it_works/

Options for Homes. (2016). The Options Contribution to Your Down Payment. Retrieved from Options for Homes: http://www.optionsforhomes.ca/boost/

Options for Homes. (2016). Vision, Mission and Values. Retrieved from Options for Homes: http://www.optionsforhomes.ca/vision/

Options for Homes. (2016). Why Options. Retrieved from Options for Homes: http://www.optionsforhomes.ca/why_options/

Painter, G., \& Redfearn, C. L. (2002). The Role of Interest Rates in Influencing Long-Run Homeownership Rates. Journal of Real Estate Finance and Economics, 25(2/3), 243-267.

Phang, S.-Y. (2010). Affordable homeownership policy. International Journal of Housing Markets and Analysis, 3(1), 38-52.

Province of Ontario. (2014). Provincial Policy Statement, 2014.

Province of Ontario. (2016). Ontario's Long-Term Affordable Housing Strategy Update. Ministry of Municipal Affairs and Housing. 
Province of Ontario. (2016). Planning Act, R.S.O. 1990, C. P.13.

Province of Ontario. (2017). Housing Services Act, 2011, S. O. 2011, C. 6, Sched. 1.

Region of Peel. (2014). Peel's Housing and Homelessness Plan - A Community Strategy 2014-2024.

Region of Peel. (2016). Region of Peel Official Plan.

Region of Peel. (n.d.). Apply for Social Housing. Retrieved from Region of Peel: https://www.peelregion.ca/housing/social/

Region of Peel. (n.d.). Housing Initiatives. Retrieved from Peel Living: https://www.peelregion.ca/housing/initiatives-resources/programs/

Region of Peel. (n.d.). Housing Initiatives - Social Housing in Peel. Retrieved from Peel Living: https://www.peelregion.ca/housing/initiatives-resources/programs/social.htm

Region of Peel. (n.d.). Peel Living. Retrieved from Peel Living: https://www.peelregion.ca/housing/peelliving/

Rolnik, R. (2013). Late Neoliberalism: The Financialization of Homeownership and Housing Rights. International Journal of Urban and Regional Research, 37.3, 1058-1066.

Ryerson University: Centre for Urban Research and Land Development. (n.d.). Greater Toronto/Hamilton Area (GTHA) Government-Owned Public Lands Web Map. Retrieved from Ryerson University: http://www.ryerson.ca/cur/Research/governmentpubliclandswebmap/

Sekkat, K., \& Szafarz, A. (2011). Valuing Homeownership. Journal of Real Estate Finance and Economics, 43, 491-504.

Statistics Canada. (2011). Shelter-cost-to-income ratio. Retrieved from Statistics Canada: https://www12.statcan.gc.ca/nhs-enm/2011/ref/dict/households-menageo28-eng.cfm

Statistics Canada. (2016). Census Profile Mississauga. 2016 Census Data.

Statistics Canada. (2017, 02 09). New Housing Price Index. Retrieved from Statistics Canada: http://www.statcan.gc.ca/tables-tableaux/sum-som/lo1/csto1/manuf12-eng.htm

Statistics Canada. (1981). CHASS 1981 cumulative. Census subdivision, Mississauga. Statistics Canada. (1986). CHASS 1986 cumulative. Census subdivision, Mississauga. Statistics Canada. (1991). CHASS 1991 cumulative. Census subdivision, Mississauga. Statistics Canada. (1996). CHASS 1996 cumulative. Census subdivision, Mississauga. Statistics Canada. (2001). CHASS 2001 cumulative. Census subdivision, Mississauga. Statistics Canada. (2006). CHASS 2006 cumulative. Census subdivision, Mississauga.

Statistics Canada. (2011). CHASS 2011 NHS. Census subdivision, Mississauga.

Statistics Canada. (2016). Census Profile Mississauga. 2016 Census Data.

Swidler, S. (2011). Homeownership: yesterday, today and tomorrow. Journal of Financial Economic Policy, 3, 5-11.

We Own. (2003, October 02). Limited Equity Coops. Retrieved from We Own: http://www.weown.net/LimitedEquityCoops.htm 


\section{GLOSSARY}

\section{Acceptable Housing}

Housing that is adequate in condition, suitable in size and affordable (Canada Mortgage and Housing Corporation, 2016)

\section{Adequate Housing}

Housing that does not require any major repairs, according to residents (Canada Mortgage and Housing Corporation, 2016)

\section{Affordable Housing}

Housing that costs less than 30\% of before-tax household income (Canada Mortgage and Housing Corporation, 2016)

\section{Butterfly Effect}

Refers to the concept that a small change will result in larger changes in the future

\section{Core Housing Need}

A household that does not meet one or more of the adequacy, suitability or affordability standards, and it would have to spend more than $30 \%$ of its before-tax income to access acceptable local housing (Canada Mortgage and Housing Corporation, 2016)

\section{Debt-to-income ratio}

A measure that calculates debt payment to overall income. This is expressed as a percentage and indicates the household debt compared to the overall household income (Investopedia, 2017)

\section{Deciles}

10 equal groups that a population can be divided into based on a particular variable. In this paper, decile refer to 10 equal income brackets (City of Mississauga, 2016)

\section{Deep Housing Affordability Issues}

Households that spend $50 \%$ of more of the household income on housing costs (City of Mississauga, 2016)

\section{High income households}

In this paper, refers to household between 7 and 10 (City of Mississauga, 2016)

\section{Housing Affordability Issues}

Households that spend $30 \%$ or more of the household income on housing costs (City of Mississauga, 2016)

\section{Loan-to-value ratio (LTV)}

A measure that calculates the mortgage amount to overall value of the home. This is expressed as a percentages and indicates the household mortgage compared to the overall purchase price of a home. For example, households purchasing a home with a $20 \%$ down payment will negotiate a mortgage that has an LTV of 80\%. (Investopedia, 2017) 


\section{Low income households}

In this paper, refers to households between decile 1 and 3 (City of Mississauga, 2016)

Moderate income households

In this paper, refers to households between decile 4 and 6 (City of Mississauga, 2016)

\section{Overvaluation}

The market price of a house is higher than the calculated value based on fundamental conditions. The market price or purchase price is higher than the assessed value. (Investopedia, 2017)

\section{Recent Immigrants}

Immigrants that migrated to Canada within the last 5 years (City of Mississauga, 2016)

\section{Repeat Sales Indices}

Refers to the changing prices for the same piece of real estate (Investopedia, 2017)

\section{Royal Assent}

The final stage in which a Bill is passed by the Houses of Parliament and becomes a law

\section{Second Unit}

a self-contained living unit within a detached, semi-detached house or townhouse (City of Mississauga, n.d.)

\section{Service Managers}

Regional authorities that deliver housing services to their local areas

\section{Severe Housing Affordability Issues}

Households that spend $70 \%$ of more of the household income on housing costs (City of Mississauga, 2016)

\section{Shelter-cost-to-income ratio}

Percentage of a households' average total monthly income which is spent on shelter related expenses (Statistics Canada, 2011)

\section{Suitable Housing}

Housing that has enough bedrooms for the size and makeup of resident households, according to national Occupancy Standard (NOS) requirements (Canada Mortgage and Housing Corporation, 2016)

\section{Urban Containment}

Attempts to shape development and the distribution of good and services in a defined space to optimize the quality of life and minimize negative implications caused by development. These are usually introduced through land use policy documents. (Nelson) 